\title{
The myogenic kinome: protein kinases critical to mammalian skeletal myogenesis
}

\author{
James DR Knight ${ }^{1,2}$ and Rashmi Kothary ${ }^{1,2,3^{*}}$
}

\begin{abstract}
Myogenesis is a complex and tightly regulated process, the end result of which is the formation of a multinucleated myofibre with contractile capability. Typically, this process is described as being regulated by a coordinated transcriptional hierarchy. However, like any cellular process, myogenesis is also controlled by members of the protein kinase family, which transmit and execute signals initiated by promyogenic stimuli. In this review, we describe the various kinases involved in mammalian skeletal myogenesis: which step of myogenesis a particular kinase regulates, how it is activated (if known) and what its downstream effects are. We present a scheme of protein kinase activity, similar to that which exists for the myogenic transcription factors, to better clarify the complex signalling that underlies muscle development.
\end{abstract}

Keywords: protein kinase, satellite cell, myoblast, myocyte, myotube, proliferation, differentiation, fusion, hypertrophy, myogenesis

\section{Review}

Embryonic myogenesis is a multistep process that begins with the commitment of an embryonic precursor to the myogenic lineage, followed by the proliferation of these committed myoblasts, the differentiation of myoblasts into postmitotic myocytes, and finally fusion of myocytes to form a multinucleated myotube. As the myotube matures, the syncytial cell becomes specialized for its particular function, with the bulk of the cytoplasm occupied by the contractile apparatus, and where the myotube/myofibre can further grow or hypertrophy in response to appropriate stimuli. Postnatal myogenesis is a similar process, except that fusion occurs primarily between myoblasts and preexisting myotubes, and where the role of the embryonic precursor is played by the quiescent satellite cell.

The process of myogenesis is controlled by several myogenic transcription factors that act as terminal effectors of signalling cascades and produce appropriate developmental stage-specific transcripts. The concerted roles that these transcription factors play is well known and well reviewed (see, for example, Sabourin and

\footnotetext{
* Correspondence: rkothary@ohri.ca

'Regenerative Medicine Program, Ottawa Hospital Research Institute, 501

Smyth Road, Ottawa, ON, K1H 8L6, Canada

Full list of author information is available at the end of the article
}

Rudnicki [1] and Le Grand and Rudnicki [2]). Pairedbox protein 7 (Pax7) maintains a population of quiescent satellite cells and, together with myogenic factor 5 (Myf5), plays a role in the expansion of activated myoblasts. Myoblast determination protein (MyoD) is believed to determine the differentiation potential of an activated myoblast, and acts together with myogenin and myocyte enhancer factor 2 (MEF2) to drive differentiation. Finally, muscle-specific regulatory factor 4 (MRF4) is required for hypertrophy, although it may have other roles as well. Obviously, these transcription factors do not act alone, but exist as part of complex signalling cascades that control every stage of myogenesis. One of the major components of these cascades is the protein kinase, an enzyme that directs cell behaviour through the simple but reversible process of phosphorylation. Over 500 kinases exist in humans and mice [3,4]; however, a myogenic scheme of protein kinase activity, similar to that which exists for the above-named transcription factors, has not previously been elaborated.

In this review, we summarize the involvement of the different protein kinases that participate in myogenesis. We discuss the stages they are required for, how they are activated during development/regeneration, and what the consequences of their activation are in terms of immediate phosphorylations and the downstream 
processes regulated. We discuss only developmental and regenerative skeletal myogenesis, in particular that of mammals, as cardiomyogenesis and the myogenesis of other vertebrate and invertebrate species contain unique features that require separate discussion. As dozens of kinases have been implicated in controlling some stage of myogenesis, this review covers the major players, those for which there is substantial evidence documenting their involvement (Figure 1).

\section{Protein kinase $\mathrm{A}$}

Protein kinase A (PKA), or cAMP-dependent protein kinase, was discovered over 40 years ago, the second protein kinase to be described [5]. It is involved in a

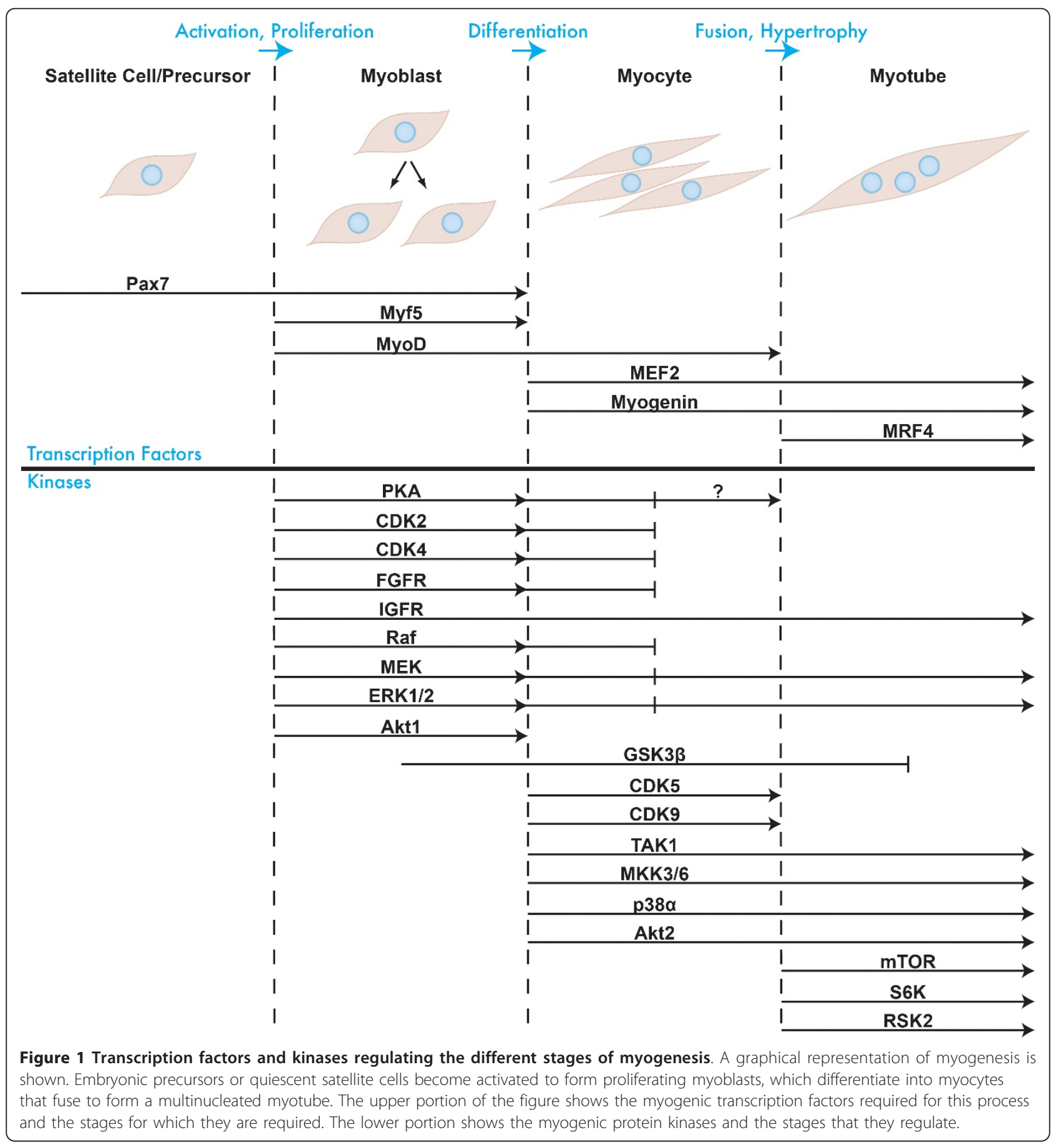


multitude of cellular processes and has hundreds of substrates [6]. In its inactive form, it exists as a holoenzyme containing two catalytic and two regulatory subunits. Each regulatory subunit can bind $\mathrm{cAMP}$, and binding triggers dissociation of the holoenzyme and the release/ activation of the catalytic subunits. Elevation in intracellular cAMP levels is therefore the primary mechanism of activation for PKA.
PKA is required at multiple stages during myogenesis, but an initial requirement is found during embryogenesis and the formation of myogenic precursors (i.e. myoblasts) within the dermomyotome (Figure 2). PKA activity is required for the expression of $\mathrm{Pax} 3, \mathrm{MyoD}$ and Myf5 in cells of the dermomyotome that will transition to form the myotome proper [7]. This activity is initiated by the release of Wnt1 and Wnt7a from the

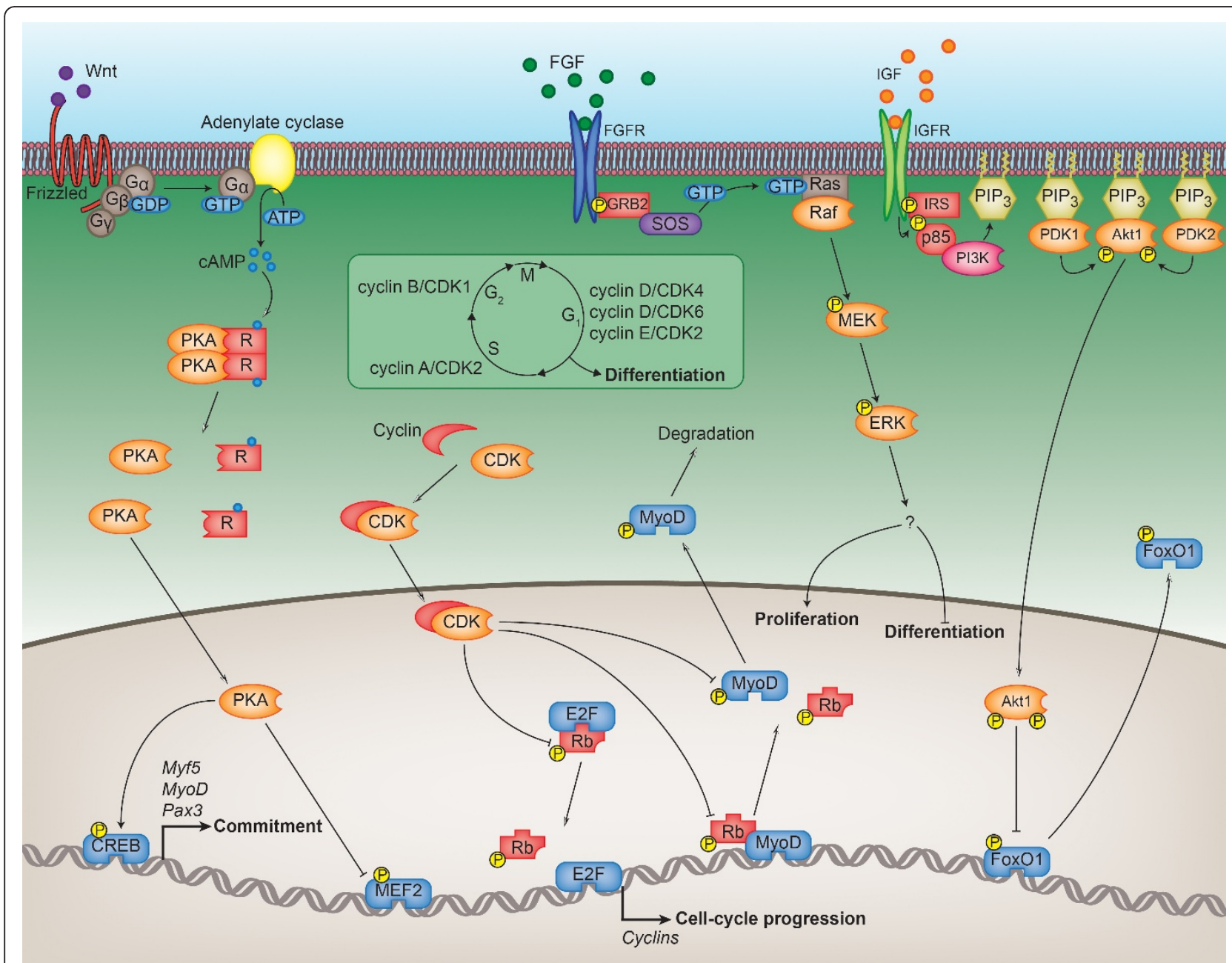

Figure 2 Regulation of the early myogenic transcriptional program by the kinome. The figure shows the mechanisms by which the kinases described in the text coordinate embryonic precursor activation, myoblast proliferation and the prevention of premature myoblast differentiation. Wnt1 and Wnt7a stimulation of precursor cells activates protein kinase A (PKA), which, through the phosphorylation of CREB, induces the expression of the myogenic transcription factors Myf5, MyoD and Pax3, resulting in the myogenic commitment of embryonic precursors. PKA then prevents the premature differentiation of proliferating myoblasts by phosphorylating and inhibiting the transcriptional activity of MEF2D. The cyclin-dependent kinases (CDKs) regulate cell cycle transitions and are activated at the appropriate time by the availability of their respective cyclins, depicted in the boxed inset. Cell cycle progression is achieved by the CDKs through the phosphorylation of Rb, which, when phosphorylated, is unable to bind and inhibit the E2F family of transcription factors that promote the expression of genes involved in cell division. Phosphorylation of Rb by the CDKs also prevents it from associating with and transactivating MyoD, thereby inhibiting cell cycle exit and differentiation. Cell cycle exit is further prevented by the proteolytic degradation of MyoD that results from direct CDK phosphorylation. The extracellular signal-regulated kinase (ERK) is activated by growth factors such as fibroblast growth factor and insulin-like growth factor (IGF), although the substrates ERK acts on to promote proliferation and inhibit differentiation are unknown. IGF also activates the Akt1 pathway and stimulates proliferation when myoblasts are subconfluent. Phosphorylation of FoxO1 by Akt1 prevents this transcription factor from accumulating in the nucleus, inhibiting the expression of genes involved in cell cycle exit, such as p27. 
dorsal neural tube and surface ectoderm, respectively, which activate heteromeric $\mathrm{G}$ proteins and adenylate cyclase to produce cAMP, activating PKA. As PKA has many substrates, the expression of these myogenic genes is likely accomplished through several different targets, but at least one of these is the transcription factor cAMP response-element binding protein (CREB). Phosphorylation of CREB by PKA allows it to initiate the transcription of genes that contain a CRE element, two of which are Pax3 and Myf5. Chen et al. [7] showed that phosphorylated CREB is present at high levels in cells of the dermomyotome that express Pax3, MyoD and $M y f 5$ and that this phosphorylation is critical for the induction of these genes. What is interesting about PKA with regards to myogenesis is that although it triggers the expression of several myogenic transcription factors, it also acts to suppress their transcription activity. It has been shown that PKA can inhibit the activity of Myf5, MyoD, myogenin and MEF2D without affecting their ability to bind DNA [8-10]. In the case of the MRFs, this appears to occur via an intermediary mechanism as opposed to direct phosphorylation, but in the case of MEF2D it is direct.

It is not clear what happens at the onset of differentiation with regards to PKA, although previous results suggest that PKA activity ultimately drops as differentiation proceeds, at least in $\mathrm{C} 2 \mathrm{C} 12$ cells [11]. Obviously, its repressive effect on the MRFs and MEF2D must be removed for differentiation to occur, and this could arise through a reduction in cAMP levels, but what happens to cAMP upon differentiation is uncertain. Different groups have reported conflicting results regarding cAMP levels and their effect on myoblast differentiation in secondary cell lines [9,11-14]. What seems clear from a recent study utilizing primary myoblasts and $\mathrm{C} 2 \mathrm{C} 12$ cells is that cAMP does not have an inhibitory effect on differentiation, but rather enhances both fusion- and differentiation-associated hypertrophy [15]. Although PKA activity would presumably be involved as a consequence of elevated cAMP, this was not convincingly shown, as the inhibitor used in that study (H89) is not absolutely specific to PKA. It was convincingly shown, however, that the appropriate localisation of PKA is critical for the positive myogenic effect of cAMP and that this appropriate localisation may be to lamellipodia. Early work on PKA and myoblast differentiation in L6 cells revealed that the establishment of appropriate levels of the regulatory and catalytic subunits of PKA is critical for differentiation $[16,17]$. It may be that PKA activity and cAMP are inhibitory to differentiation when present in certain areas (the nucleus, for example) and positive when found in other areas (lamellipodia). The repressive effect that PKA has upon the MRFs and MEF2D could be removed by a change in localisation or increased nuclear association of the catalytic subunit with its regulatory subunits, and this change may go hand in hand with a positive effect of PKA elsewhere in the cell. Ultimately, more detailed work on the role of PKA and cAMP during myoblast differentiation needs to be done to resolve these issues.

\section{Cyclin-dependent kinases}

The cyclin-dependent kinases (CDKs) take their name from a catalytic dependence on the cyclin family of regulatory proteins. There are several cyclins and CDKs that collectively control cell cycle progression as well as other processes. The cyclins, and by extension the CDKs, can be divided into three major groups: the $G_{1}$ cyclins, which regulate progression through $G_{1}$ and entry into $\mathrm{S}$ phase; the mitotic cyclins, which regulate entry into mitosis; and the non-cell cycle cyclins, which have cell cycle-independent roles. This last group is not a typical classification, but we introduce it here because this group of cyclins/CDKs is important for myogenesis. The $G_{1}$ cyclins include cyclins $D$ and $E$, and are responsible for activating CDK4 (cyclin D), CDK6 (cyclin D) and CDK2 (cyclins D and E). The mitotic cyclins $\mathrm{A}$ and $B$ activate CDK2 (cyclin A) and CDK1 (cyclin B). Levels of these cyclins are regulated by intrinsic cell cyclederived signals, with the exception of cyclin $\mathrm{D}$, which is regulated largely by extrinsic signals such as growth factors [18]. The final group of cyclins that have prominent roles outside the cell cycle include p35 and cyclin T, which activate CDK5 and CDK9, respectively. p35 is technically not a cyclin family member, but it activates CDK5 in the same allosteric manner as cyclins activate their CDKs and so we include it here.

In all cell types, the $G_{1}$ and mitotic cyclins/CDKs regulate cell cycle progression and proliferation, and myoblasts are no different (Figure 2). One of the major mechanisms by which cell cycle progression is mediated is through CDK-dependent phosphorylation of the retinoblastoma protein $(\mathrm{Rb})$. When phosphorylated, $\mathrm{Rb}$ is unable to bind and inhibit the E2F family of transcription factors, whose activities drive cell cycle progression. In proliferating myoblasts, the CDKs have an additional role in preventing precocious differentiation. Cyclin E/ CDK2 and cyclin D/CDK4 can both block differentiation and the transcriptional activity of MyoD [19-24]. Cyclin E/CDK2 blocks MyoD-induced gene expression through the phosphorylation of $\mathrm{Rb}$ [22], preventing $\mathrm{Rb}$ from binding and transactivating MyoD [25], and triggering $\mathrm{S}$ phase entry instead of differentiation. Overexpression (or the natural accumulation in myoblasts) of MyoD is one well-known way to drive myogenic differentiation, even in nonmyogenic cell lines. Cyclin E/CDK2 can phosphorylate MyoD at serine 200 [26-28], which causes ubiquitination and degradation of this transcription 
factor during $G_{1}[28,29]$, preventing its accumulation and a commitment to differentiation. Phosphorylation of MyoD at S200 is common to other CDKs, such as the mitotic cyclin B/CDK1 [26], which may prevent inappropriate $\mathrm{MyoD}$ accumulation during mitosis. In contrast to CDK2, cyclin D/CDK4 blocks MyoD activity through an as yet unclear mechanism that may involve direct binding [22,30,31]. Cyclin D/CDK4 can also block the activity of myogenin and all MEF2 isoforms [31]. Not much is known about how this occurs, but inhibition of MEF2C by CDK4 prevents the association of MEF2 with its transcriptional coactivator, glucocorticoid receptor-interacting protein 1 (GRIP1) [31]. Whether CDK6 also plays a role in preventing differentiation is unknown, although the mechanisms by which the CDKs block differentiation are likely much more complex than what we present here.

For myoblasts to differentiate, the cell cycle must be exited and the restraints the CDKs place on differentiation must be removed. Differentiation cues, such as serum withdrawal or cell-cell contact in cultured cells, elicit several effects that ultimately cause a decrease in $\mathrm{G}_{1}$ and mitotic CDK activity. The expression of cyclin D1, CDK1, CDK2 and CDK6 drop with differentiation, while cyclins $\mathrm{A}, \mathrm{B}$ and $\mathrm{E}$ may also decrease [19-21,23,26,32-41]. At the same time as the expression levels of these proteins decline, there is an increase in the levels of the two families of CDK inhibitors (CKIs): the inhibitor of CDK4 family (INK4) and the cyclindependent kinase-interacting protein/kinase-inhibitory protein family (CIP/KIP). The INK4 family includes p15, p16, p18 and p19, and, despite the family name, these members also inhibit CDK6. The CIP/KIP members include p21, p27 and p57, and these members inhibit all $\mathrm{G}_{1}$ CDKs. There is substantial evidence demonstrating the importance of the CKIs for myoblast differentiation in vitro and in vivo. The expression levels of $\mathrm{p} 16, \mathrm{p} 18$, p19, p21, p27 and p57 all increase with differentiation $[27,33,35,38,39,41-46]$, there is a sharp increase in p27 levels in the myotome at the onset of development [47], and mice lacking p21 and p57 form defective muscles [48]. When myoblasts are cued to differentiate, the CKIs bind and inhibit the $G_{1}$ and mitotic CDKs $[23,33,35,36,39,41]$, and do so throughout differentiation and even in adult tissue, which is important as not all cell cycle CDKs are lost with differentiation [20,23,27,35-38]. Unlike the other cyclins mentioned, cyclin D3 levels increase with differentiation, during which process this cyclin interacts strongly with CDK2 and CDK4 [19-21,36,37,39,41,49]. However, CDK-containing cyclin D3 complexes lack activity, suggesting that cyclin D3 may fulfil a necessary role as part of an inhibitory complex during differentiation. The end result of these changes in protein expression, whether it be cyclins, CDKs or CKIs, is a net loss of cell cycle CDK activity [26,32,33,35,37-39], hypophosphorylation of Rb $[34,36,38]$, cell cycle exit, accumulation of MyoD [27], and leave for myoblasts to differentiate.

Once the cell cycle CDKs have been effectively silenced and the cell cycle exited, the non-cell cycle CDKs are important for promoting and establishing differentiation (Figure 3). These include CDK5 and CDK9, which are not inhibited by the CKIs discussed above. The expression of the CDK5-activating protein p35 is induced with myoblast differentiation and during muscle regeneration, the more stable and active calpain cleavage product of $\mathrm{p} 35(\mathrm{p} 25)$ increases as differentiation progresses, and the activity of CDK5 subsequently increases [50-53]. Dominant-negative CDK5 that lacks activity inhibits both differentiation and fusion $[50,51,54]$, although the mechanisms by which CDK5 activity promotes these processes are not clear. In myoblasts, CDK5 can interact with, phosphorylate and regulate nestin [51], a negative regulator of differentiation, while nestin in turn can feed back and control CDK5 activity by preventing the processing of p35 into p25 [54]. Through a bidirectional relationship, CDK5 and nestin appear to control the rate at which myoblast differentiation occurs. Like CDK5, the activity of CDK9 also increases with differentiation, and this activity is critical for both in vitro differentiation and in vivo regeneration following injury [55-57]. Overexpression of it (or its activating cyclin T2) accelerates differentiation, at least in part through enhancing the activity of MyoD [55]. Cyclin T2/CDK9 can interact with and phosphorylate MyoD, although the consequences of phosphorylation are not known [55,57]. The interaction between these components, however, is critical for MyoD to induce gene expression. The recruitment of cyclin T2/CDK9 by MyoD to muscle-specific loci is believed to result in the phosphorylation and activation of RNA polymerase II by CDK9, thereby inducing transcription of myogenic genes [56]. Needless to say, what is known about these non-cell cycle CDKs and their role in differentiation is very partial, but highlights how the CDK family of kinases regulates myogenesis in a number of ways.

\section{Extracellular signal-regulated kinase (FGFR, Raf, MEK, RSK2)}

Extracellular signal-regulated kinase (ERK) was first identified as an insulin-sensitive kinase that could phosphorylate the microtubule-associated protein 2, hence its original name 'MAP2 kinase' or 'MAP2K' [58]. It was later given the more general name 'ERK' [59], as its activity can be stimulated by a variety of growth factors/ mitogens and it has many substrates in addition to MAP2. It is still generally known as 'MAPK', but with 'MAPK' now an acronym for 'mitogen-activated protein 


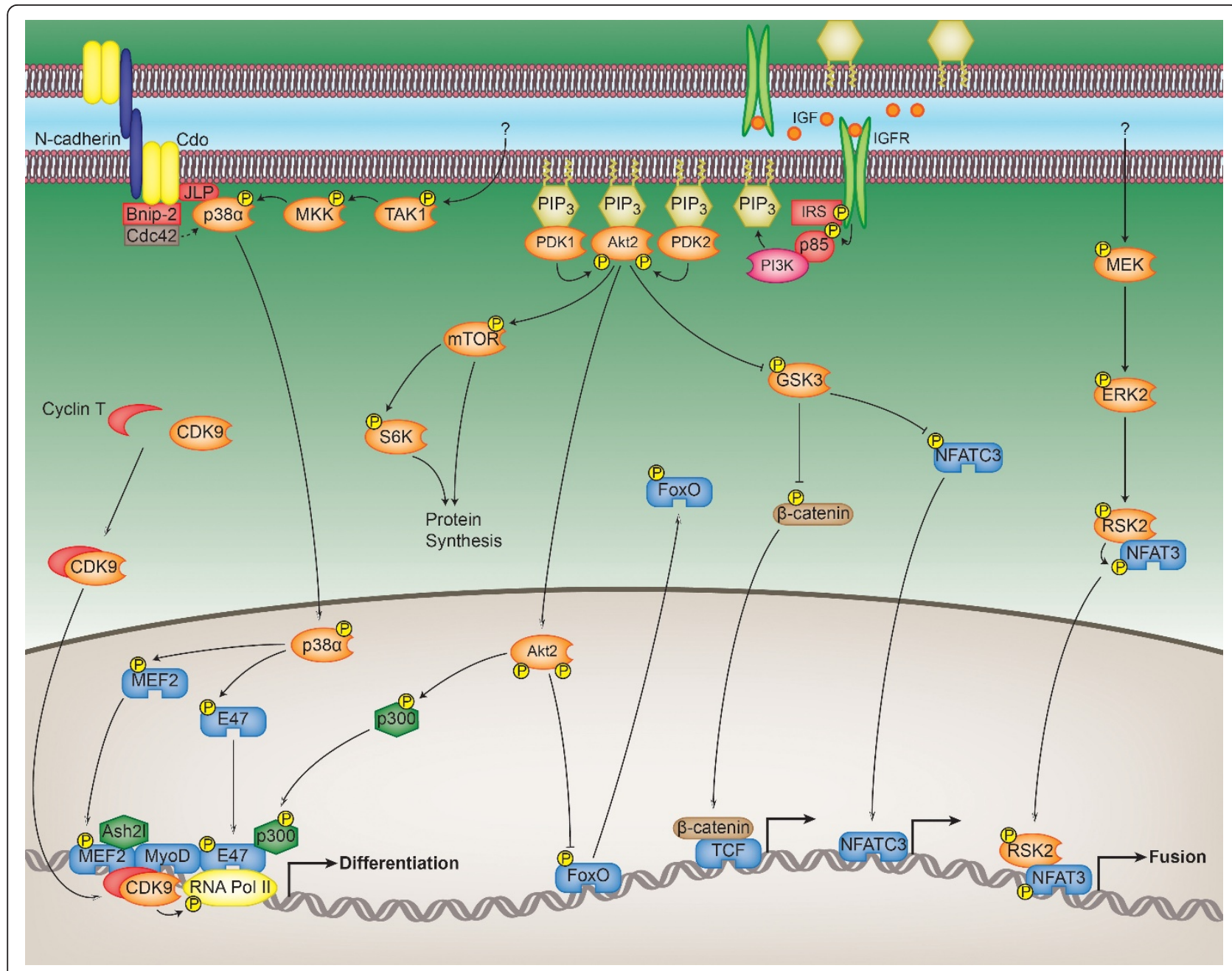

Figure 3 Regulation of the late myogenic transcriptional program by the kinome. The figure shows the mechanisms by which the kinases described in the text coordinate myoblast cell cycle exit, myoblast differentiation, myocyte fusion and myotube hypertrophy. Cell-cell contact and $\mathrm{N}$-cadherin ligation, in conjunction with transforming growth factor- $\beta$-activated kinase 1 (TAK1) and MAP kinase kinase 3/6 (MKK), activate p38 $\alpha$. p38 $\alpha$ induces cell cycle exit and differentiation through the phosphorylation of MEF2 and E47 that together with MyoD form part of an active myogenic transcriptional complex. A subunit of this complex is RNA polymerase II (RNA Pol II), which is phosphorylated and activated by cyclin-dependent kinase 9 (CDK9). Akt2, in response to IGF stimulation, phosphorylates the transcriptional coactivator and histone

acetyltransferase p300, which is part of the same myogenic transcriptional complex. Activation of the Akt2 pathway promotes differentiation and hypertrophy by several other mechanisms as well. Akt2 phosphorylates and inactivates the FoxO family of transcription factors, whose activities are inhibitory to differentiation and hypertrophy. Phosphorylation of the mammalian target of rapamycin (mTOR) by Akt2 encourages protein synthesis/hypertrophy, partly through mTOR's phosphorylation and activation of the ribosomal protein S6 kinase 1 (S6K). Akt2 can also phosphorylate and inhibit glycogen synthase kinase $3 \beta$ (GSK3). When active, GSK3 inhibits differentiation and hypertrophy through phosphorylation and cytoplasmic sequestration of NFATC3. Phosphorylation of $\beta$-catenin by GSK3 similarly prevents its nuclear accumulation and ability to activate the TCF/LEF family of transcription factors. Finally, activation of extracellular signal-regulated kinase 2 (ERK2) by an unknown stimulus promotes cell fusion through the phosphorylation and nuclear accumulation of NFAT3 via the 90-kDa ribosomal S6 kinase 2 (RSK2).

kinase'. There are several ERK isoforms, and there are other kinases that go by the name 'ERK', but generally, when used, the name refers to isoforms ERK1 and ERK2.

ERK1 and ERK2 (ERK1/2) belong to a well-defined pathway (Figure 2) that is activated by growth factor stimulation of a receptor tyrosine kinase, such as the binding of fibroblast growth factor (FGF) to its receptor
(FGFR). Autophosphorylation of the growth factor receptor follows ligand binding and initiates the formation of an adaptor complex through Src homology 2 (SH2) domain-containing proteins such as GRB2. GRB2 interacts with the guanine-nucleotide exchange factor SOS, and localisation of these two proteins to the plasma membrane near the GTPase Ras allows SOS to catalyse GTP exchange and activation of Ras. GTP- 
bound Ras then binds and activates Raf, initiating the MAP kinase cascade. Raf is a MAP kinase kinase kinase (MAP3K) that phosphorylates and activates the dualspecificity MAP or ERK kinase (MEK), which in turn phosphorylates and activates ERK1/2.

Myoblasts/myocytes have a unique biphasic requirement for ERK activity. ERK1/2 is critical for growth factor-induced cellular proliferation, inhibitory to myoblast differentiation, and later required for myocyte fusion, or at least ERK2 appears critical to this last process. One previous publication also suggested that the Raf-MEKERK pathway might play a role in maintaining satellite cell quiescence [60], but further experimentation is required before this can be accepted. What is disappointing about the research that has been done on this pathway and its role during myogenesis, or rather on ERK's role in particular, is that virtually no ERK target phosphorylations have been studied or even identified. It is assumed that relevant substrates will be canonical ERK targets that have been studied in other cell types, but this has not been shown and there may very well be novel muscle-specific substrates as well. Research has instead focused on discovery and further description of the stages of myogenesis that ERK regulates, with some insight into secondary mechanisms, but almost nothing on direct substrates and their role in the myogenic process. With that in mind, we shall proceed with a discussion of what is known about the function of ERK and this pathway during myoblast proliferation and differentiation.

Evidence from primary cell cultures suggests a critical role for ERK in myoblast proliferation [61,62], which is supported by extensive data from secondary cell lines. In myoblasts, ERK activity can be stimulated by a variety of growth factors. Serum, a complex mixture of mitogens, activates ERK [63-66], but FGF [64,67-71], hepatocyte growth factor (HGF) [61], insulin-like growth factor (IGF) $[66,67,70,72-74]$, leukaemia-inhibitory factor (LIF) [75], and platelet-derived growth factor (PDGF) $[73,76]$ can do so in isolation. Not all of these growth factors elicit the same response from ERK, however. FGF, HGF and IGF activate ERK to induce or maintain proliferation $[61,67,69-72,77]$, while PDGF does not but can enhance survival $[73,76]$. During proliferation, ERK activity prevents cell cycle exit during $\mathrm{G}_{1}$ [78], and FGF/ ERK's role during myoblast proliferation may be to prevent cell cycle exit and promote entry into $S$ phase $[69,79]$. How ERK accomplishes these functions, and particularly how different responses are elicited from it by different growth factors, is unknown. Of the different ERK-inducing growth factors, FGF has been the best studied in the context of myoblast proliferation, and the signalling cascade that results from FGF stimulation is as described above [69-71,80,81], although it should be mentioned that FGF appears to affect proliferation by an additional ERK-independent pathway as well $[69,82]$.

Although almost nothing is known about how ERK positively affects myoblast proliferation, not much more is known about how it prevents premature differentiation, although it is clear that it does. ERK only mediates this effect for certain growth factors, however. IGF and FGF can both stimulate ERK activity, but once cells reach confluency in culture, IGF stimulation promotes differentiation [66,72] while FGF stimulation prevents it $[64,68-70,76,83-89]$. This is likely due to IGF's ability to induce other pathways in addition to that of ERK (see Akt section below), and demonstrates how the role that ERK activity is playing needs to be considered within the physiological context in which it occurs. In the context of FGF-induced activity, the Ras-Raf-MEK-ERK pathway is able to inhibit differentiation $[62,64,70,78,81,88-100]$ by preventing the nuclear accumulation of MEF2 [96], and preventing the expression of certain myogenic factors, including MyoD [85-87,101-104], the CDK inhibitor p21 [94,95] and other transcriptional regulatory proteins [105]. ERK's and FGF's ability to prevent myoblast differentiation is supported by the biochemical observation that during differentiation FGF receptors are lost $[106,107]$ and the activity of ERK decreases [52,66,81,92,95,97,108]. Again it appears that this critical role of ERK in blocking differentiation occurs specifically during $G_{1}$ [84], possibly as an inhibitory cue that prevents the accumulation of proteins that would drive cells into a postmitotic phenotype. As mentioned, the substrates that ERK acts on to prevent myoblast differentiation are unknown.

ERK activity does initially decrease with myoblast differentiation, which is necessary for differentiating myoblasts to overcome the inhibitory effect that it has, but ERK's activity comes back on as differentiation proceeds [66,92,93,95,97,104,108-110]. ERK activity, and specifically that of the ERK2 isoform, is critical for myocyte fusion and survival (Figure 3) $[77,92,93,95,104,109]$. ERK can phosphorylate and activate the 90-kDa ribosomal S6 kinase 2 (RSK2), which positively regulates myocyte fusion through phosphorylation and transcriptional activation of nuclear factor of activated $\mathrm{T}$ cell 3 (NFAT3) [111]. ERK activity also stimulates the transcriptional activity of MyoD by an as yet to be described mechanism [104], and, contrary to ERK's role in myoblasts, it now enhances the expression of p21 [95,110]. There may be uncoupling of the Raf-MEK-ERK pathway during myocyte fusion as there are contradictory data on the function of Raf, with different reports describing both positive and negative roles for it $[94,98,104,110]$, although it is clear that both MEK and ERK play positive roles. Similarly, FGF is certainly inhibitory to fusion, and so the growth factor or mechanism stimulating ERK 
activity in myocytes is unknown and the pathway promoting this activity needs further elucidation.

\section{p38 $\alpha$ (TAK1, MKK3/6)}

The p38 family of MAPKs are closely related to the ERK MAPKs discussed above, and take their rather unimaginative name from their apparent molecular weight. The $\alpha$ isoform of the p38 family was initially identified as an effector of the cellular stress response [112-115], but has also been shown to be critical for the differentiation of numerous cell types [116-121]. There are three other p38 isoforms, $\beta, \gamma$ and $\delta$, but only p38 $\alpha$ appears uniformly critical for differentiation, with the other isoforms either unnecessary or with insufficient evidence supporting an essential role.

At the turn of the century, several groups reported a critical role for one of or both the p38 $\alpha$ and $\beta$ isoforms during myoblast differentiation $[95,97,122-125]$. It was found that p38 activity was induced during differentiation in culture and that inhibition of the $\alpha$ and $\beta$ isoforms blocked the induction and/or activation of myogenic and muscle-specific genes, as well as prevented myocyte fusion. These studies were all performed with secondary cell lines (C2C12, L6E9, L8 and transformed $10 \mathrm{~T} 1 / 2$ ), but in vivo work has confirmed that p38 activity is indeed critical for myoblast differentiation. During embryonic development, p38 activity is induced in somites, and inhibition does not affect the myogenic commitment of cells but does block the induction of the myotomal muscle marker myosin light chain 3F (MLC3F) [126]. Most recently, the group of Pura Muñoz-Cánoves has demonstrated through isoform-specific knockout in mice that $\mathrm{p} 38 \alpha$ is absolutely critical for the differentiation of primary myoblasts, while $\beta$ and $\delta$ are not necessary for either differentiation or cardiotoxin-induced regeneration, and the $\gamma$ isoform appears necessary only for optimal fusion of myoblasts [127-129]. It should be noted, however, that a discrepancy may exist between primary myoblasts and $\mathrm{C} 2 \mathrm{C} 12$ cells, as the $\alpha, \beta$ and $\gamma$ isoforms all appear to be essential for C2C12 differentiation [125,130,131], highlighting that the model system being used always needs to be taken into consideration.

Cell-cell contact in myoblast cultures triggers precocious differentiation, and contact is at least one mechanism by which p38 $\alpha$ is activated (Figure 3 ). N-cadherin ligation between cells initiates the formation of a complex that includes the cell surface protein Cdo and scaffolding proteins that recruit p38 in addition to other components [132-134]. Precisely how this complex results in p38 activation is not known, but complex recruitment of the GTPase Cdc42 is required for p38 phosphorylation. However, as noted by Kang et al. [133], although Cdo complex formation appears to be a major mechanism behind p38 activation in differentiating myoblasts, it is likely not the only mechanism, as there are additional ways to activate p38 in the absence of Cdo complex components. Transforming growth factor $\beta$-activated kinase 1 (TAK1) is an upstream activating MAP3K that is essential for myoblast differentiation in a p38-dependent manner [135], and activation of this kinase is traditionally associated with transforming growth factor (TGF) stimulation as opposed to N-cadherin ligation. TAK1 can phosphorylate and activate MAP kinase kinase 3/6 (MKK3/6), and numerous studies have demonstrated a requirement for MKK3/6 activity in the initiation of myoblast differentiation, again in a p38-dependent manner. Whether $\mathrm{N}$-cadherin ligation and Cdo are coupled to TAK1 and MKK3/6 is not known, and so it is not possible to present a clear pathway for p38 activation during differentiation.

Once activated, p38 is involved in multiple prodifferentiation processes (Figure 3). It has a powerful ability to trigger cell cycle exit, and can even force cell cycle exit in rhabdomyosarcoma cells [136]. The mechanisms by which it does so have not been well elucidated, but it can downregulate canonical proliferation markers such as cyclins $\mathrm{A}, \mathrm{D}$ and $\mathrm{E}$, as well as phosphorylated $\mathrm{Rb}$ $[127,128,137]$. Chromatin remodelling is a candidate mechanism by which p38 activity might trigger the downregulation of cell cycle-related genes. p38 can phosphorylate the histone-lysine $\mathrm{N}$-methyltransferase $\mathrm{EZH} 2$, the catalytic subunit of the polycomb repressive complex 2 (PRC2), with phosphorylation of EZH2 necessary for PRC2's association with the transcriptional repressor YY1 and subsequent chromatin remodelling [138]. One target of this complex in myoblasts is the Pax7 promoter, and downregulation of Pax7 is a necessary step before differentiation can occur.

At the same time as p38 creates a repressive chromatin environment for $\mathrm{Pax} 7$ and possibly other genes, it creates a permissive environment at myogenic loci. p38 phosphorylates the BAF60 subunit of the SWI-SNF chromatin remodelling complex, and p38 recruits this complex to differentiation-specific loci $[137,139]$. Through phosphorylation of MEF2D, p38 recruits an Ash2l-containing complex to myogenic loci during differentiation, which results in the marking of these genes for expression [140]. As a permissive environment is created at these loci, p38 further stimulates gene expression through the phosphorylation of additional myogenic transcription factors, including MEF2C [95,123,126] and E47 [141]. Phosphorylation of MEF2C is necessary for its transcriptional activation, and E47 phosphorylation allows heterodimerisation with and activation of MyoD. p38 also plays a critical role in activating other myogenic factors. Nuclear translocation of p65 during differentiation is p38-dependent [142], as is 
MyoD activity [95,123,125,127,136], partly through E47 phosphorylation and heterodimerisation but likely via other means as well. Ultimately, through these and possibly other mechanisms, p38 has the ability to affect the expression of a multitude of genes. Some of those directly relevant to differentiation and not already mentioned include Akt [143,144], caveolin 3 [124] and IGF2 [145].

The responsibility of p38 during myoblast differentiation is not limited to gene regulation, but includes a critical role in other processes as well. Briata et al. [146] showed that p38 phosphorylates the mRNA decay-promoting $\mathrm{KH}$ type-splicing regulatory protein (KSRP). Phosphorylation prevents KSRP from associating with select transcripts, resulting in transcript stabilization, and in the case of differentiating myoblasts this allows for the accumulation of mRNA for at least two very critical myogenic proteins: the CDK inhibitor p21 and myogenin. Also, current work from our own laboratory shows that during myoblast differentiation active p38 accumulates in the cytoplasm and can phosphorylate dozens of cytosolic proteins with a variety of known functions, suggesting that the role of p38 during myogenesis likely goes far beyond gene regulation (JDR Knight, R Tian, REC Lee, F Wang, H Zou, LA Megeney, D Figeys, R Kothary, unpublished work).

Finally, it needs to be mentioned that the literature is not in complete consensus regarding the role of p38 during myoblast differentiation. A potentially conflicting result was published by Weston et al. [147], who showed that inhibiting $\mathrm{p} 38 \alpha / \beta$ in a mixed culture of primary limb mesenchymal cells supports and accelerates the terminal differentiation of myocytes. Specifically, cells that already express myosin heavy chain appear to undergo accelerated fusion and/or hypertrophy, along with an increased expression of myogenic markers following p38 inhibition. These results suggest that in this type of heterogeneous environment, p38 activity, in concert with a particular milieu of factors released by nonmyogenic cells, may serve to restrict the late stages of myocyte differentiation, or that obstructing p38 activity in nonmyogenic cells present in the coculture results in the release of potent myogenic factors that drive terminal myocyte differentiation even in the absence of active p38. As no further work has been done on this model system and more experiments are required, it is not possible to reconcile these findings with the extensive data produced using other models.

\section{Akt (IGFR, GSK3 3, mTOR, S6K)}

The protein kinase Akt first became known as the product of the oncogenic $v$-akt gene of the Akt8 murine retrovirus [148]. The retroviral oncogene has three mammalian cellular homologues (Akt1, Akt2 and $A k t 3)$ that code for a protein kinase with an N-terminal pleckstrin homology $(\mathrm{PH})$ domain [148-153]. Owing to its independent discovery by three separate groups, it has two additional names: protein kinase $\mathrm{B}(\mathrm{PKB})$ and the related to the $\mathrm{A}$ and $\mathrm{C}$ kinases (RAC-PK), on the basis of its homology $[149,151]$

Akt forms part of a well-studied pathway (Figure 3), and for a review, see, for example, the articles by Glass [154] and Franke [155]. This pathway mediates the effects of insulin and IGF and includes several kinases that shall be discussed together here, although focus is placed on Akt. The pathway is activated by the binding of IGF to the IGF receptor (or of insulin to the insulin receptor), and, like most growth factor receptors, IGFR contains a tyrosine kinase domain that autoactivates upon ligand binding. A principal target of IGFR is the insulin receptor substrate (IRS), which, when phosphorylated, recruits the lipid kinase phosphatidylinositol 3-kinase (PI3K) through the $\mathrm{SH} 2$ domain of its regulatory subunit (p85), triggering activation of the catalytic subunit. PI3K produces the membrane-bound phosphatidylinositol (3,4)-bisphosphate $\left(\mathrm{PI}(3,4) \mathrm{P}_{2}\right)$ and phosphatidylinositol $(3,4,5)$-trisphosphate $\left(\mathrm{PI}(3,4,5) \mathrm{P}_{3}\right)$ from $\mathrm{PI}(4)$ $\mathrm{P}$ and $\mathrm{PI}(4,5) \mathrm{P}_{2}$, respectively. These phosphoinositide products localise $\mathrm{PH}$ domain-containing proteins to the plasma membrane, including Akt, the constitutively active phosphoinositide-dependent kinase 1 (PDK1), and "PDK2". The colocalisation of these kinases allows for PDK1 and PDK2 to phosphorylate Akt at distinct sites, with both phosphorylations necessary for activation. PDK2 is not a single kinase but rather a group of kinases [156], any one of which has the ability to phosphorylate Akt at the required site. Two major kinase targets of Akt are the mammalian target of rapamycin (mTOR) and glycogen synthase kinase $3 \beta$ (GSK3 $\beta$ ). Phosphorylation of mTOR by Akt activates it, resulting in an increase in protein synthesis, while Akt's phosphorylation of GSK3 $\beta$ inactivates this kinase, thereby removing the restraint that GSK3 $\beta$ places on differentiation and hypertrophy. One final, well-characterized member of this pathway is the ribosomal protein S6 kinase 1 (S6K), which is phosphorylated and activated by mTOR to positively and further regulate protein translation.

This pathway, with Akt at its heart, is activated by IGF or insulin stimulation, but there is evidence to suggest that Akt can be activated by other mechanisms in muscle cell lines. Elia et al. [157] showed that Sonic hedgehog $(\mathrm{SHH})$ can stimulate Akt phosphorylation and myogenic gene expression, and, similar to work done on the p38 pathway, Bae et al. [158] showed that Akt can be activated from cell-cell contact through Cdo activation and the recruitment of the Akt-interacting partner APPL1. There is evidence to suggest that APPL1 may 
function downstream of insulin in myoblasts $[159,160]$, indicating that cell-cell contact and insulin/IGF may cooperate to activate Akt. Whether $\mathrm{SHH}$ also cooperates with this pathway or stimulates one in parallel is unclear, but there is certainly more to be discovered about the mechanisms of Akt activation.

While the pathway of Akt activation requires additional elaboration, the importance of the IGF-Akt axis to myogenesis cannot be debated. It has been demonstrated in culture that IGF is critical to, and a potent stimulator of, myoblast differentiation and hypertrophy, and that muscle cell lines upregulate IGF2 upon differentiation [87,161-167]. These results carry over in vivo, as IGF overexpression in mice triggers myoblast differentiation, myofibre hypertrophy and regeneration [168-170]. Several studies have shown that Akt activity is induced during myoblast differentiation, and that its activity is critical for the induction of differentiation and hypertrophy both in culture and in vivo [52,94,125,144,171-175]. IGF can also have a positive effect on myoblast proliferation under certain conditions, and Akt may be critical for proliferation as well $[176,177]$, although the details regarding this pathway are poorly understood. We shall discuss the proliferative capabilities of IGF and Akt in greater detail below after first introducing the different Akt isoforms and their respective myogenic responsibilities.

IGF can activate any of the three Akt isoforms, and currently both Akt1 and Akt 2 have been implicated in myogenesis, while Akt3 has not. There is very strong evidence to suggest that isoforms 1 and 2 are required at different stages, although how their activation is differentially controlled is unknown. Protein levels of Akt1 remain constant from proliferating to differentiating cells, whereas the levels and activity of Akt2 increase with differentiation [143,176,178-181]. Consistent with these observations, Akt2 drives differentiation [176,177,181-183], while Akt1 appears critical to myoblasts for proliferation but is dispensable for differentiation and may even be inhibitory to the latter process when activated alone $[176,177,183,184]$. Conversely, Akt2 is dispensable for proliferation and cannot rescue Akt1 knockdown in proliferating myoblasts [176,177]. It should be noted, however, that overexpression of a constitutively active mutant of either isoform can initiate and drive differentiation, but this is likely an artefact that results from artificially elevated Akt levels. It is difficult to be conclusive at the moment, especially as little work has been done in vivo or in primary cells, but there is certainly strong evidence to support distinct roles for Akt1 and Akt2 during myogenesis.

When myoblasts are initially treated with IGF, there is a proliferative response and differentiation is prevented $[67,72,74,177,185-187]$. This response is induced largely when myoblasts are subconfluent and is mediated in part by IGF-induced phosphorylation of ERK1/2, as well as Akt1 (Figure 2). Few targets of Akt1 in proliferative myoblasts are known, but once activated, Akt1 phosphorylates the cyclin kinase inhibitor p21, triggering its dissociation from CDK2 and leading to cell cycle progression [74,177]. Akt can also phosphorylate forkhead box protein $\mathrm{O} 1$ (FoxO1) in myoblasts, with phosphorylation blocking nuclear translocation of the transcription factor and inhibiting expression of FoxO1-regulated transcripts such as the CDK inhibitor $p 27$ [187]. Evidence suggests that this IGF proliferative pathway can be turned off either by inhibiting ERK1/2, or through the activation of Akt2 [72,94,99,177]. Once confluent, cell-cell contact is known to antagonize ERK1/2 activation in other cell types [188-191], and in myoblasts confluency induces p38 activity as described in the previous section, which in turn leads to the upregulation of $A k t 2$ transcript levels [143]. Contrary to Akt1, Akt2 interacts with p21 but does not phosphorylate it, and instead appears to prevent phosphorylation by Akt1 [177]. This Akt2-p21 complex can then inhibit CDK2 and allow cell cycle exit and differentiation. Hence the switch from an IGF-induced proliferative response to an induction of differentiation may be controlled largely by the degree of cell-cell contact present.

Once Akt2 becomes activated, it triggers myoblast cell cycle exit (Figure 3). It does so by phosphorylating the pituitary homeobox 2 (Pitx2) transcription factor (which cannot be phosphorylated by Akt1) [192]. Pitx2 interacts with the mRNA binding protein HuR to stabilize cyclin D1 transcript levels to maintain proliferation, while Akt2 phosphorylation of Pitx2 causes dissociation of this complex and degradation of cyclin D1 mRNA. Once cell cycle exit has occurred, Akt's phosphorylation (and inhibition) of the FoxO family of transcription factors now allows differentiation to occur [193], as these transcription factors, although apparently necessary for cell cycle exit in myoblasts [187], are inhibitory to differentiation. Akt activity is also critical for the production of myogenic transcripts, partly through positive regulation of MyoD and MEF2C transcriptional activities $[172,181,194]$. Akt can phosphorylate the transcriptional coactivator $\mathrm{p} 300$, which results in the formation of an active p300-MyoD complex [137]. In myoblasts, MyoD and MEF2 activities are suppressed, partly from being bound to the transcriptional repressor prohibitin 2 (PHB2). Akt2 can remove this repression through binding to and downregulating PHB2 [183,195], allowing MyoD and MEF2 transcriptional activation, although whether Akt2-mediated phosphorylation of PHB2 occurs is unknown. A further factor that triggers differentiation in response to Akt activity is the phosphorylation and inactivation of GSK3 $\beta$. When active, GSK3 $\beta$ represses 
myoblast differentiation and fusion [182,196-198] through inhibitory phosphorylations of $\beta$-catenin and NFATC3. The silencing of GSK3 $\beta$ activity by Akt allows for the accumulation and nuclear translocation of $\beta$ catenin $[182,198]$, resulting in the activation of the TCF/ LEF family of transcription factors. GSK3 $\beta$ 's phosphorylation of NFATC3 hides this transcription factor's nuclear localisation signal, thereby preventing nuclear accumulation and transcription of its dependent genes, while Akt's phosphorylation and inhibition of GSK3 $\beta$ allows this NFATC3 accumulation to occur $[197,198]$. The end result of GSK3 $\beta$ inactivation is the activation of transcription factors that initiate the production of numerous myogenic transcripts.

Following commitment to differentiation, Akt is further required for the growth/hypertrophy of myotubes (Figure 3). Its multifaceted role during hypertrophy is emphasized by the fact that the exogenous overexpression of myogenic factors such as MyoD or myogenin cannot compensate for the absence of Akt activity during this process [199]. During hypertrophy, Akt is still responsible for phosphorylating and inactivating GSK3 $\beta$ as it was at the onset of differentiation, as GSK3 $\beta$ is inhibitory to both stages of myogenesis $[173,198,200,201]$. Similarly, Akt's phosphorylation of the FoxO family of transcription factors is necessary not just for differentiation but also for hypertrophy. FoxO activity stimulates expression of the atrophy-inducing, muscle-specific ubiquitin ligases MAFbx and MuRF1 $[202,203]$, and Akt therefore blocks the expression of these ligases. One of the most well-studied downstream targets of Akt in muscle is mTOR, whose phosphorylation and activity are induced during hypertrophy [204]. mTOR itself is in fact required for both differentiation and hypertrophy $[72,122,174]$, but its kinase activity is required only for the latter [204-209]. Approximately $90 \%$ of the genes regulated by IGF in differentiating myoblasts are mTOR-dependent [210], emphasizing the importance of this kinase as a hypertrophic IGF effector. mTOR, together with S6K, an mTOR substrate whose activity is induced during and critical to hypertrophy $[72,108,122,175,204,205,209,211]$, trigger protein synthesis and growth by initiating cap-dependent translation. mTOR activity also leads to the upregulation of miR-1, which inhibits HDAC4 expression, thereby allowing the upregulation of critical myogenic genes, including the profusion protein follistatin [212].

A substantial amount of research on the IGF-Akt signalling axis has been conducted, and we have briefly summarized it here. Further research regarding the distinct roles of Akt1 and Akt2 is required: if, in fact, there is a distinction; how they are differentially regulated; and the similarities and differences between downstream targets. Over 100 Akt substrates are known, but very few have been studied during myogenesis. We have described the handful of substrates that have been studied, but this must be a very incomplete picture, and so there is still much room for further exploration.

\section{Conclusions}

As we have reviewed here, the differential activation (and inhibition) of distinct protein kinases acts to control the formation of a mature myotube from a population of embryonic precursors or satellite cells. Although there is more to be discovered, a synthesis of the available information reveals a kinase hierarchy that coordinates myogenesis in a fashion analogous to the myogenic transcription factors. Initially, during development, and likely via analogous mechanisms during juvenile and adult myogenesis, the presence of specific Wnts induces PKA activity and the myogenic commitment of precursors to form a pool of dividing myoblasts. Growth factors, and likely other extrinsic components, then activate ERK1/2, Akt1 and cyclin D/CDK2, 4 and 6 to promote proliferation, which, along with PKA, act simultaneously to restrict differentiation. Intrinsic cell cycle-derived signals regulate the levels of cyclins A, B and $\mathrm{E}$, which, together with their respective CDKs, promote cell cycle progression and inhibit differentiation. As the myoblast population expands to the threshold of available space, cell-cell contact can turn off ERK, and a decline in certain growth factors can further silence ERK and downregulate cyclin D/CDK2, 4 and 6 activity, to inhibit additional proliferation. With the silencing of ERK and cell cycle CDK activity, and proliferation lessening, cell-cell contact can promote differentiation through p38 and possibly Akt 2 as well. Certain unknown cues may also relocalise PKA activity to remove its restraint on differentiation while allowing it to have a positive effect elsewhere in the cell. Similarly, undefined signals lead to an upregulation of p35 and cyclin $\mathrm{T}$ levels to induce the activity of CDK5 and 9, respectively. An increasing concentration of IGF, which is released during differentiation, stimulates Akt2 activity to drive differentiation and hypertrophy, and elevated IGF levels may also induce ERK2 activity at later time points to promote fusion. Finally, as differentiation progresses, p38 activity relocalises to the cytoplasm, where it promotes the mid to late stages of differentiation.

The protein kinase scheme we present herein demonstrates how a number of kinases are used by myogenic cells to transition from state to state, and the intricate signalling used to coordinate the proper development of muscle tissue. As complex as is the picture we offer, it is only partial. Not only does more need to be known about the kinases we have discussed, but there are many other kinases that have been implicated in controlling some aspect of myogenesis (Table 1). As research on 
Table 1 Other protein kinases implicated in myogenesis

\begin{tabular}{|c|c|c|c|c|}
\hline Stage $^{a}$ & Kinase & Full name & Mechanism $^{\mathbf{b}}$ & References \\
\hline $\begin{array}{l}\text { Satellite cell } \\
\text { activation }\end{array}$ & c-Met ${ }^{c}$ & $\begin{array}{l}\mathrm{N} \text {-methyl- } \mathrm{N}^{\prime} \text {-nitro- } \mathrm{N} \text {-nitrosoguanidine (MNNG) human } \\
\text { osteosarcoma (HOS) transforming oncogene cellular } \\
\text { homologue }\end{array}$ & ? & [213-215] \\
\hline \multirow[t]{3}{*}{$\begin{array}{l}\text { Proliferation and/or } \\
\text { inhibit differentiation }\end{array}$} & JAK1 & Janus/just another kinase 1 & $\begin{array}{l}\text { Phosphorylation and activation of } \\
\text { STAT1 }\end{array}$ & [216] \\
\hline & p38r & p38y mitogen-activated protein kinase & $\begin{array}{l}\text { Phosphorylation and repression of } \\
\text { MyoD activity }\end{array}$ & [217] \\
\hline & ROCK1 & Rho-associated kinase 1 & $\begin{array}{l}\text { Blocks activation of the Akt } \\
\text { differentiation pathway }\end{array}$ & [218-220] \\
\hline \multirow[t]{7}{*}{ Differentiation } & $c-A b l$ & $\begin{array}{l}\text { Abelson murine leukaemia viral } \\
\text { oncogene cellular homologue }\end{array}$ & Activation of p38 & {$[221,222]$} \\
\hline & $\begin{array}{l}\text { CaMK1/ } \\
4\end{array}$ & Calcium/calmodulin-dependent protein kinases 1 and 4 & $\begin{array}{l}\text { Phosphorylates HDAC5, thereby } \\
\text { releasing repression of MEF2 }\end{array}$ & [223-226] \\
\hline & DYRK1B & Dual-specificity tyrosine phosphorylation-regulated kinase $1 \mathrm{~B}$ & $\begin{array}{l}\text { Phosphorylates HDAC5 and HDAC9, } \\
\text { thereby releasing repression of MEF2 }\end{array}$ & {$[227,228]$} \\
\hline & MAPK $7^{d}$ & Mitogen-activated protein kinase 7 & $\begin{array}{l}\text { Phosphorylation and activation of } \\
\text { MEF2C }\end{array}$ & {$[229,230]$} \\
\hline & JAK2 & Janus/just another kinase 2 & $\begin{array}{l}\text { Phosphorylation and activation of } \\
\text { STAT2 and STAT3 }\end{array}$ & {$[216,231]$} \\
\hline & PKC $\zeta$ & Protein kinase $\mathrm{C} \zeta$ & Activation of CDK5 & [53] \\
\hline & PKD2 & Protein kinase D2 & $\begin{array}{l}\text { Activation of MEF2D and repression of } \\
\text { Pax3 }\end{array}$ & [232] \\
\hline \multirow[t]{3}{*}{ Fusion } & cGK1 & Cyclic GMP-dependent protein kinase 1 & $\begin{array}{l}\text { Phosphorylation and inactivation of } \\
\text { FoxO1 }\end{array}$ & [233] \\
\hline & FAK & Focal adhesion kinase & Fusogen expression & {$[234,235]$} \\
\hline & PKC $\theta$ & Protein kinase $\mathrm{C} \theta$ & Activation of FAK & [234] \\
\hline Hypertrophy & ROCK2 & Rho-associated kinase 2 & Activation of ERK2 and S6K & [236] \\
\hline
\end{tabular}

The protein kinases listed are those that have been clearly implicated in regulating some aspect of myogenesis but have not been studied in detail.

${ }^{\mathrm{a}}$ The stage of myogenesis regulated by the indicated kinase. ${ }^{\mathrm{b}}$ The mechanism the indicated kinase has been implicated in regulating. ${ }^{\mathrm{C}} \mathrm{Also}$ known as hepatocyte

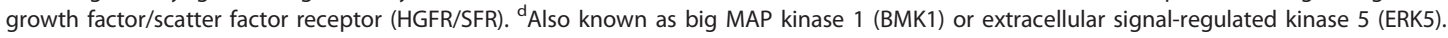

muscle development continues, it will be interesting to learn how these other kinases fit in with the picture presented here. It is important to state that much of what is known about kinases and myogenesis relates either to myoblast proliferation, differentiation or myotube hypertrophy, while very little is known about the kinase signalling that regulates satellite cell quiescence and activation, as well as myocyte fusion. While Pax7 is a well-established marker and regulator of satellite cells, almost nothing is known about the protein kinases that regulate satellite cell quiescence or maintenance. With respect to fusion, not only is there limited information about the kinases that control this process, but little is known about it in general, which is surprising, considering its obvious importance to the most unique feature of muscle tissue: the multinucleated cell. Although fusion and hypertrophy are the end stage of our description of myogenesis, further stages could be added, including precursor migration, sarcomere formation and neuromuscular junction development. The prospect of a comprehensive review on myogenic signalling is an almost overwhelming one, due to the number of different cell states, processes and network complexity involved, but we hope to have begun clarifying it.

\section{Abbreviations}

Akt: $v$-akt murine thymoma viral oncogene cellular homologue, a.k.a. protein kinase $B(P K B)$, a.k.a. the related to the $A$ and $C$ kinases (RAC-PK); APPL1: adapter protein containing PH domain, PTB domain and leucine zipper motif 1; Ash2l: Ash2-like methyltransferase; BAF60: BRG1-associated factor 60; Cdc42: cell division control protein 42; CDK: cyclin-dependent kinase; Cdo: cell adhesion molecule-related/downregulated by oncogenes; CIP/KIP: cyclindependent kinase-interacting protein/kinase-inhibitory protein; CKI: CDK inhibitor; CREB: CAM̄MP response element-binding protein; ERK: extracellular signal-regulated kinase, a.k.a. microtubule-associated protein 2 kinase (MAP2K); EZH2: enhancer of zeste homologue 2; FGF: fibroblast growth factor; FGFR: fibroblast growth factor receptor; FoxO1: forkhead box protein 01; GFR: growth factor receptor; GRB2: growth factor receptor-bound protein 2; GRIP-1: glucocorticoid receptor-interacting protein 1; GSK3 $\beta$ : glycogen synthase kinase 3ß; HDAC: histone deacetylase; HGF: hepatocyte growth factor; HuR: human antigen R; IGF: insulin-like growth factor; IGFR: insulin-like growth factor receptor; INK4: inhibitor of cyclin-dependent kinase 4; IRS: insulin-receptor substrate; KSRP: KH type-splicing regulatory protein;

LIF: leukaemia-inhibitory factor; MAFbx: muscle atrophy F box; MAPK: mitogen-activated protein kinase; MAP3K: mitogen-activated protein kinase kinase kinase; MEF2: myocyte enhancer factor 2; MEK: dual-specificity MAP or ERK kinase; MKK3/6: mitogen-activate protein kinase kinase 3/6; MRF4: muscle-specific regulatory factor 4; mTOR: mammalian target of rapamycin; MuRF1: muscle RING finger 1; Myf5: myogenic factor 5; MyoD: myoblast determination protein; NFAT3: nuclear factor of activated T cell 3; p38: p38 
mitogen-activated protein kinase; p65/RelA: v-rel reticuloendotheliosis viral oncogene cellular homologue A; Pax7: paired-box protein 7; PDGF: plateletderived growth factor; PDK1: phosphoinositide-dependent kinase; PH: pleckstrin homology; PHB2: prohibitin 2; PI3K: phosphatidylinositol 3-kinase; $\mathrm{PI}(3,4) \mathrm{P}_{2}$ : phosphatidylinositol (3,4)-bisphosphate; $\mathrm{PI}(3,4,5) \mathrm{P}_{3}$ : phosphatidylinositol (3,4,5)-trisphosphate; PI(4)P: phosphatidylinositol 4phosphate; $\mathrm{PI}(4,5) \mathrm{P}_{2}$ : phosphatidylinositol (4,5)-bisphosphate; Pitx2: pituitary homeobox 2; PKA: protein kinase A, a.k.a. cAMP-dependent protein kinase; PRC2: polycomb repressive complex 2; Rb: retinoblastoma protein; RSK2: 90kDa ribosomal S6 kinase 2; S6K: ribosomal protein S6 kinase 1; SH2: Src homology 2; SHH: Sonic hedgehog; SOS: son of sevenless; STAT: signal transducer and activator of transcription; SWI-SNF: switch/sucrose nonfermentable; TAK1: transforming growth factor $\beta$-activated kinase 1; TCF/ LEF: T-cell factor/lymphoid enhancer-binding factor; TGF: transforming growth factor; Wnt: wingless/int; YY1: yin and yang 1.

\section{Acknowledgements}

We thank Dr Lyndsay Murray for critical reading of the manuscript. JDRK is supported by a Vanier Canada Graduate Scholarship from the Canadian Institutes of Health Research. RK is a recipient of a University Health Research Chair from the University of Ottawa (Ottawa, ON, Canada).

\section{Author details}

${ }^{1}$ Regenerative Medicine Program, Ottawa Hospital Research Institute, 501 Smyth Road, Ottawa, ON, K1H 8L6, Canada. ${ }^{2}$ Department of Cellular and Molecular Medicine, University of Ottawa, 451 Smyth Road, Ottawa, ON, K1H 8M5, Canada. ${ }^{3}$ Department of Medicine, University of Ottawa, 451 Smyth Road, Ottawa, ON, K1H 8M5, Canada.

\section{Authors' contributions}

JDRK wrote the manuscript. RK revised and edited the manuscript. Both authors read and approved the final manuscript.

\section{Competing interests}

The authors declare that they have no competing interests.

Received: 13 June 2011 Accepted: 8 September 2011

Published: 8 September 2011

\section{References}

1. Sabourin LA, Rudnicki MA: The molecular regulation of myogenesis. Clin Genet 2000, 57:16-25

2. Le Grand F, Rudnicki MA: Skeletal muscle satellite cells and adult myogenesis. Curr Opin Cell Biol 2007, 19:628-633.

3. Manning G, Whyte DB, Martinez R, Hunter T, Sudarsanam S: The protein kinase complement of the human genome. Science 2002, 298:1912-1934.

4. Caenepeel S, Charydczak G, Sudarsanam S, Hunter T, Manning G: The mouse kinome: discovery and comparative genomics of all mouse protein kinases. Proc Natl Acad Sci USA 2004, 101:11707-11712.

5. Walsh DA, Perkins JP, Krebs EG: An adenosine 3',5'-monophosphatedependant protein kinase from rabbit skeletal muscle. J Biol Chem 1968, 243:3763-3765.

6. Shabb JB: Physiological substrates of cAMP-dependent protein kinase. Chem Rev 2001, 101:2381-2411.

7. Chen $A E$, Ginty DD, Fan CM: Protein kinase A signalling via CREB controls myogenesis induced by Wnt proteins. Nature 2005, 433:317-322.

8. Li L, Heller-Harrison R, Czech M, Olson EN: Cyclic AMP-dependent protein kinase inhibits the activity of myogenic helix-loop-helix proteins. Mol Cell Biol 1992, 12:4478-4485.

9. Winter B, Braun T, Arnold HH: cAMP-dependent protein kinase represses myogenic differentiation and the activity of the muscle-specific helixloop-helix transcription factors Myf-5 and MyoD. J Biol Chem 1993, 268:9869-9878.

10. Du M, Perry RLS, Nowacki NB, Gordon JW, Salma J, Zhao J, Aziz A, Chan J, Siu KWM, McDermott JC: Protein kinase A represses skeletal myogenesis by targeting myocyte enhancer factor 2D. Mol Cell Biol 2008, 28:2952-2970

11. Siow NL, Choi RCY, Cheng AWM, Jiang JXS, Wan DCC, Zhu SQ, Tsim KWK: A cyclic AMP-dependent pathway regulates the expression of acetylcholinesterase during myogenic differentiation of $\mathrm{C} 2 \mathrm{C} 12$ cells. $J$ Biol Chem 2002, 277:36129-36136.
12. $\mathrm{Hu} J \mathrm{~S}$, Olson EN: Regulation of differentiation of the $\mathrm{BC} 3 \mathrm{H} 1$ muscle cell line through CAMP-dependent and -independent pathways. J Biol Chem 1988, 263:19670-19677.

13. Salminen A, Braun $T$, Buchberger $A$, Jürs $S$, Winter $B$, Arnold HH: Transcription of the muscle regulatory gene MYF4 is regulated by serum components, peptide growth factors and signaling pathways involving G proteins. J Cell Biol 1991, 115:905-917.

14. De Arcangelis V, Coletti D, Conti M, Lagarde M, Molinaro M, Adamo S, Nemoz G, Naro F: IGF-l-induced differentiation of L6 myogenic cells requires the activity of cAMP-phosphodiesterase. Mol Biol Cell 2003, 14:1392-1404.

15. Mukai A, Hashimoto N: Localized cyclic AMP-dependent protein kinase activity is required for myogenic cell fusion. Exp Cell Res 2008, 314:387-397.

16. Rogers JE, Narindrasorasak S, Cates GA, Sanwal BD: Regulation of protein kinase and its regulatory subunits during skeletal myogenesis. J Biol Chem 1985, 260:8002-8007.

17. Lorimer IA, Sanwal BD: Regulation of cyclic AMP-dependent protein kinase levels during skeletal myogenesis. Biochem J 1989, 264:305-308.

18. Murray AW: Recycling the cell cycle: cyclins revisited. Cell 2004, 116:221-234.

19. Rao SS, Chu C, Kohtz DS: Ectopic expression of cyclin D1 prevents activation of gene transcription by myogenic basic helix-loop-helix regulators. Mol Cell Biol 1994, 14:5259-5267.

20. Skapek SX, Rhee J, Spicer DB, Lassar AB: Inhibition of myogenic differentiation in proliferating myoblasts by cyclin D1-dependent kinase. Science 1995, 267:1022-1024.

21. Rao SS, Kohtz DS: Positive and negative regulation of D-type cyclin expression in skeletal myoblasts by basic fibroblast growth factor and transforming growth factor $\beta$ : a role for cyclin D1 in control of myoblast differentiation. J Biol Chem 1995, 270:4093-4100.

22. Skapek SX, Rhee J, Kim PS, Novitch BG, Lassar AB: Cyclin-mediated inhibition of muscle gene expression via a mechanism that is independent of pRB hyperphosphorylation. Mol Cell Biol 1996, 16:7043-7053.

23. Guo K, Walsh K: Inhibition of myogenesis by multiple cyclin-Cdk complexes: coordinate regulation of myogenesis and cell cycle activity at the level of E2F. J Biol Chem 1997, 272:791-797.

24. Saab R, Bills JL, Miceli AP, Anderson CM, Khoury JD, Fry DW, Navid F, Houghton PJ, Skapek SX: Pharmacologic inhibition of cyclin-dependent kinase 4/6 activity arrests proliferation in myoblasts and rhabdomyosarcoma-derived cells. Mol Cancer Ther 2006, 5:1299-1308.

25. Gu W, Schneider JW, Condorelli G, Kaushal S, Mahdavi V, Nadal-Ginard B: Interaction of myogenic factors and the retinoblastoma protein mediates muscle cell commitment and differentiation. Cell 1993, 72:309-324.

26. Kitzmann M, Vandromme M, Schaeffer V, Carnac G, Labbé JC, Lamb N, Fernandez A: cdk1- and cdk2-mediated phosphorylation of MyoD Ser200 in growing C2 myoblasts: role in modulating MyoD half-life and myogenic activity. Mol Cell Biol 1999, 19:3167-3176.

27. Reynaud EG, Pelpel K, Guillier M, Leibovitch MP, Leibovitch SA: p57(Kip2) stabilizes the MyoD protein by inhibiting cyclin E-Cdk2 kinase activity in growing myoblasts. Mol Cell Biol 1999, 19:7621-7629.

28. Tintignac LA, Leibovitch MP, Kitzmann M, Fernandez A, Ducommun B, Meijer L, Leibovitch SA: Cyclin E-cdk2 phosphorylation promotes late G1phase degradation of MyoD in muscle cells. Exp Cell Res 2000, 259:300-307

29. Song A, Wang Q, Goebl MG, Harrington MA: Phosphorylation of nuclear MyoD is required for its rapid degradation. Mol Cell Biol 1998, 18:4994-4999.

30. Zhang JM, Wei Q, Zhao X, Paterson BM: Coupling of the cell cycle and myogenesis through the cyclin D1-dependent interaction of MyoD with cdk4. EMBO J 1999, 18:926-933.

31. Lazaro JB, Bailey PJ, Lassar AB: Cyclin D-cdk4 activity modulates the subnuclear localization and interaction of MEF2 with SRC-family coactivators during skeletal muscle differentiation. Genes Dev 2002, 16:1792-1805.

32. Jahn L, Sadoshima J, Izumo S: Cyclins and cyclin-dependent kinases are differentially regulated during terminal differentiation of $\mathrm{C} 2 \mathrm{C} 12$ muscle cells. Exp Cell Res 1994, 212:297-307. 
33. Guo K, Wang J, Andrés V, Smith RC, Walsh K: MyoD-induced expression of p21 inhibits cyclin-dependent kinase activity upon myocyte terminal differentiation. Mol Cell Biol 1995, 15:3823-3829.

34. Wang J, Nadal-Ginard B: Regulation of cyclins and $\mathrm{p} 34^{\mathrm{CDC} 2}$ expression during terminal differentiation of C2C12 myocytes. Biochem Biophys Res Commun 1995, 206:82-88.

35. Franklin DS, Xiong Y: Induction of p18INK4c and its predominant association with CDK4 and CDK6 during myogenic differentiation. $\mathrm{Mol}$ Biol Cell 1996, 7:1587-1599.

36. Wang J, Walsh K: Inhibition of retinoblastoma protein phosphorylation by myogenesis-induced changes in the subunit composition of the cyclindependent kinase 4 complex. Cell Growth Differ 1996, 7:1471-1478.

37. Tedesco D, Baron L, Fischer-Fantuzzi L, Vesco C: Induction of cyclins $E$ and $A$ in response to mitogen removal: a basic alteration associated with the arrest of differentiation of C2 myoblasts transformed by simian virus 40 large T antigen. J Virol 1997, 71:2217-2224.

38. Knudsen ES, Pazzagli C, Born TL, Bertolaet BL, Knudsen KE, Arden KC, Henry RR, Feramisco JR: Elevated cyclins and cyclin-dependent kinase activity in the rhabdomyosarcoma cell line RD. Cancer Res 1998, 58:2042-2049.

39. Chu CY, Lim RW: Involvement of $p 27^{\mathrm{kip} 1}$ and cyclin D3 in the regulation of cdk2 activity during skeletal muscle differentiation. Biochim Biophys Acta 2000, 1497:175-185.

40. Latella L, Sacco A, Pajalunga D, Tiainen M, Macera D, D'Angelo M, Felici A, Sacchi A, Crescenzi M: Reconstitution of cyclin D1-associated kinase activity drives terminally differentiated cells into the cell cycle. Mol Cell Biol 2001, 21:5631-5643.

41. Peschiaroli A, Figliola R, Coltella L, Strom A, Valentini A, D'Agnano I, Maione R: MyoD induces apoptosis in the absence of RB function through a p21 $1^{\text {WAF1 }}$-dependent re-localization of cyclin/cdk complexes to the nucleus. Oncogene 2002, 21:8114-8127.

42. Halevy O, Novitch BG, Spicer DB, Skapek SX, Rhee J, Hannon GJ, Beach D, Lassar $A B$ : Correlation of terminal cell cycle arrest of skeletal muscle with induction of p21 by MyoD. Science 1995, 267:1018-1021.

43. Parker SB, Eichele G, Zhang P, Rawls A, Sands AT, Bradley A, Olson EN, Harper JW, Elledge SJ: p53-independent expression of p21 ${ }^{\text {Cip1 }}$ in muscle and other terminally differentiating cells. Science 1995, 267:1024-1027.

44. Wang J, Walsh K: Resistance to apoptosis conferred by Cdk inhibitors during myocyte differentiation. Science 1996, 273:359-361.

45. Puri PL, Balsano C, Burgio VL, Chirillo P, Natoli G, Ricci L, Mattei E, Graessmann A, Levrero M: MyoD prevents cyclin A/cdk2 containing E2F complexes formation in terminally differentiated myocytes. Oncogene 1997, 14:1171-1184.

46. Phelps DE, Hsiao KM, Li Y, Hu N, Franklin DS, Westphal E, Lee EYHP, Xiong $Y$ : Coupled transcriptional and translational control of cyclindependent kinase inhibitor $\mathrm{p} 18^{I N K 4 C}$ expression during myogenesis. $\mathrm{Mol}$ Cell Biol 1998, 18:2334-2343.

47. Zabludoff SD, Csete M, Wagner R, Yu X, Wold BJ: p27 ${ }^{\text {Kip } 1}$ is expressed transiently in developing myotomes and enhances myogenesis. Cell Growth Differ 1998, 9:1-11.

48. Zhang $\mathrm{P}$, Wong $\mathrm{C}$, Liu D, Finegold M, Harper JW, Elledge SJ: $\mathrm{p} 21^{\mathrm{CIP} 1}$ and $\mathrm{p} 57^{\mathrm{KIP} 2}$ control muscle differentiation at the myogenin step. Genes Dev 1999, 13:213-224.

49. Kiess M, Gill RM, Hamel PA: Expression of the positive regulator of cell cycle progression, cyclin D3, is induced during differentiation of myoblasts into quiescent myotubes. Oncogene 1995, 10:159-166.

50. Lazaro JB, Kitzmann M, Poul MA, Vandromme M, Lamb NJ, Fernandez A: Cyclin dependent kinase 5, cdk5, is a positive regulator of myogenesis in mouse C2 cells. J Cell Sci 1997, 110:1251-1260.

51. Sahlgren CM, Mikhailov A, Vaittinen S, Pallari HM, Kalimo H, Pant HC, Eriksson JE: Cdk5 regulates the organization of Nestin and its association with p35. Mol Cell Biol 2003, 23:5090-5106.

52. Sarker KP, Lee KY: L6 myoblast differentiation is modulated by Cdk5 via the PI3K-AKT-p70S6K signaling pathway. Oncogene 2004, 23:6064-6070.

53. de Thonel A, Ferraris SE, Pallari HM, Imanishi SY, Kochin V, Hosokawa T, Hisanaga S, Sahlgren C, Eriksson JE: Protein kinase CZ regulates Cdk5/p25 signaling during myogenesis. Mol Biol Cell 2010, 21:1423-1434.

54. Pallari HM, Lindqvist J, Torvaldson E, Ferraris SE, He T, Sahlgren C, Eriksson JE: Nestin as a regulator of Cdk5 in differentiating myoblasts. Mol Biol Cell 2011, 22:1539-1549.
55. Simone C, Stiegler P, Bagella L, Pucci B, Bellan C, De Falco G, De Luca A Guanti G, Puri PL, Giordano A: Activation of MyoD-dependent transcription by cdk9/cyclin T2. Oncogene 2002, 21:4137-4148.

56. Giacinti C, Bagella L, Puri PL, Giordano A, Simone C: MyoD recruits the cdk9/cyclin T2 complex on myogenic-genes regulatory regions. J Cell Physiol 2006, 206:807-813.

57. Giacinti C, Musarò A, De Falco G, Jourdan I, Molinaro M, Bagella L, Simone C, Giordano A: Cdk9-55: a new player in muscle regeneration. $J$ Cell Physiol 2008, 216:576-582.

58. Ray LB, Sturgill TW: Rapid stimulation by insulin of a serine/threonine kinase in 3T3-L1 adipocytes that phosphorylates microtubule-associated protein 2 in vitro. Proc Natl Acad Sci USA 1987, 84:1502-1506.

59. Boulton TG, Yancopoulos GD, Gregory JS, Slaughter C, Moomaw C, Hsu J, Cobb MH: An insulin-stimulated protein kinase similar to yeast kinases involved in cell cycle control. Science 1990, 249:64-67.

60. Reed SA, Ouellette SE, Liu X, Allen RE, Johnson SE: E2F5 and LEK translocation to the nucleus is an early event demarcating myoblast quiescence. J Cell Biochem 2007, 101:1394-1408.

61. Volonte D, Liu Y, Galbiati F: The modulation of caveolin-1 expression controls satellite cell activation during muscle repair. FASEB J 2005, 19:237-239.

62. Kook SH, Son YO, Choi KC, Lee HJ, Chung WT, Hwang $\mathrm{H}$, Lee JC: Cyclic mechanical stress suppresses myogenic differentiation of adult bovine satellite cells through activation of extracellular signal-regulated kinase. Mol Cell Biochem 2008, 309:133-141.

63. Jahn L, Sadoshima J, Izumo S: Cyclins and cyclin-dependent kinases are differentially regulated during terminal differentiation of $\mathrm{C} 2 \mathrm{C} 12$ muscle cells. Exp Cell Res 1994, 212:297-307.

64. Miralles F, Ron D, Baiget M, Félez J, Muñoz-Cánoves P: Differential regulation of urokinase-type plasminogen activator expression by basic fibroblast growth factor and serum in myogenesis: requirement of a common mitogen-activated protein kinase pathway. J Biol Chem 1998, 273:2052-2058.

65. Pizon V, Baldacci G: Rap1A protein interferes with various MAP kinase activating pathways in skeletal myogenic cells. Oncogene 2000, 19:6074-6081.

66. Adi S, Bin-Abbas B, Wu NY, Rosenthal SM: Early stimulation and late inhibition of extracellular signal-regulated kinase $1 / 2$ phosphorylation by IGF-I: a potential mechanism mediating the switch in IGF-I action on skeletal muscle cell differentiation. Endocrinology 2002, 143:511-516.

67. Milasincic DJ, Calera MR, Farmer SR, Pilch PF: Stimulation of $\mathrm{C} 2 \mathrm{C} 12$ myoblast growth by basic fibroblast growth factor and insulin-like growth factor 1 can occur via mitogen-activated protein kinasedependent and -independent pathways. Mol Cell Biol 1996, 16:5964-5973.

68. Kudla AJ, Jones NC, Rosenthal RS, Arthur K, Clase KL, Olwin BB: The FGF receptor-1 tyrosine kinase domain regulates myogenesis but is not sufficient to stimulate proliferation. J Cell Biol 1998, 142:241-250.

69. Jones NC, Fedorov YV, Rosenthal RS, Olwin BB: ERK1/2 is required for myoblast proliferation but is dispensable for muscle gene expression and cell fusion. J Cell Physiol 2001, 186:104-115.

70. Tortorella LL, Milasincic DJ, Pilch PF: Critical proliferation-independent window for basic fibroblast growth factor repression of myogenesis via the p42/p44 MAPK signaling pathway. J Biol Chem 2001, 276:13709-13717.

71. Nagata $Y$, Honda $Y$, Matsuda R: FGF2 induces ERK phosphorylation through Grb2 and PKC during quiescent myogenic cell activation. Cell Struct Funct 2010, 35:63-71.

72. Coolican SA, Samuel DS, Ewton DZ, McWade FJ, Florini JR: The mitogenic and myogenic actions of insulin-like growth factors utilize distinct signaling pathways. J Biol Chem 1997, 272:6653-6662.

73. Lawlor MA, Feng $X$, Everding DR, Sieger K, Stewart CE, Rotwein P: Dual control of muscle cell survival by distinct growth factor-regulated signaling pathways. Mol Cell Biol 2000, 20:3256-3265.

74. Chakravarthy MV, Abraha TW, Schwartz RJ, Fiorotto ML, Booth FW: Insulinlike growth factor-I extends in vitro replicative life span of skeletal muscle satellite cells by enhancing $G_{1} / S$ cell cycle progression via the activation of phosphatidylinositol 3'-kinase/Akt signaling pathway. J Biol Chem 2000, 275:35942-35952

75. Jo C, Kim H, Jo I, Choi I, Jung SC, Kim J, Kim SS, Jo SA: Leukemia inhibitory factor blocks early differentiation of skeletal muscle cells by activating ERK. Biochim Biophys Acta 2005, 1743:187-197. 
76. Kudla AJ, John ML, Bowen-Pope DF, Rainish B, Olwin BB: A requirement for fibroblast growth factor in regulation of skeletal muscle growth and differentiation cannot be replaced by activation of platelet-derived growth factor signaling pathways. Mol Cell Biol 1995, 15:3238-3246.

77. Li J, Johnson SE: ERK2 is required for efficient terminal differentiation of skeletal myoblasts. Biochem Biophys Res Commun 2006, 345:1425-1433.

78. Heller $\mathrm{H}$, Gredinger $\mathrm{E}$, Bengal $\mathrm{E}$ : Rac1 inhibits myogenic differentiation by preventing the complete withdrawal of myoblasts from the cell cycle. $J$ Biol Chem 2001, 276:37307-37316.

79. Lathrop B, Thomas K, Glaser L: Control of myogenic differentiation by fibroblast growth factor is mediated by position in the $\mathrm{G} 1$ phase of the cell cycle. J Cell Biol 1985, 101:2194-2198.

80. Weyman CM, Ramocki MB, Taparowsky EJ, Wolfman A: Distinct signaling pathways regulate transformation and inhibition of skeletal muscle differentiation by oncogenic Ras. Oncogene 1997, 14:697-704.

81. Samuel DS, Ewton DZ, Coolican SA, Petley TD, McWade FJ, Florini JR: Raf-1 activation stimulates proliferation and inhibits IGF-stimulated differentiation in L6A1 myoblasts. Horm Metab Res 1999, 31:55-64.

82. Campbell JS, Wenderoth MP, Hauschka SD, Krebs EG: Differential activation of mitogen-activated protein kinase in response to basic fibroblast growth factor in skeletal muscle cells. Proc Natl Acad Sci USA 1995, 92:870-874.

83. Spizz G, Roman D, Strauss A, Olson EN: Serum and fibroblast growth factor inhibit myogenic differentiation through a mechanism dependent on protein synthesis and independent of cell proliferation. J Biol Chem 1986, 261:9483-9488.

84. Clegg CH, Linkhart TA, Olwin BB, Hauschka SD: Growth factor control of skeletal muscle differentiation: commitment to terminal differentiation occurs in G1 phase and is repressed by fibroblast growth factor. J Cell Biol 1987, 105:949-956.

85. Vaidya TB, Rhodes SJ, Taparowsky EJ, Konieczny SF: Fibroblast growth factor and transforming growth factor $\beta$ repress transcription of the myogenic regulatory gene MyoD1. Mol Cell Biol 1989, 9:3576-3579.

86. Yoshida S, Fujisawa-Sehara A, Taki T, Arai K, Nabeshima Y: Lysophosphatidic acid and bFGF control different modes in proliferating myoblasts. J Cell Biol 1996, 132:181-193.

87. Montarras D, Aurade F, Johnson T, llan J, Gros F, Pinset C: Autonomous differentiation in the mouse myogenic cell line, $C 2$, involves a mutual positive control between insulin-like growth factor II and MyoD, operating as early as at the myoblast stage. J Cell SCi 1996, 109:551-560.

88. Weyman CM, Wolfman A: Mitogen-activated protein kinase kinase (MEK) activity is required for inhibition of skeletal muscle differentiation by insulin-like growth factor 1 or fibroblast growth factor 2. Endocrinology 1998, 139:1794-1800.

89. Peña TL, Chen SH, Konieczny SF, Rane SG: Ras/MEK/ERK up-regulation of the fibroblast $\mathrm{K}_{\mathrm{Ca}}$ channel FIK is a common mechanism for basic fibroblast growth factor and transforming growth factor- $\beta$ suppression of myogenesis. J Biol Chem 2000, 275:13677-13682.

90. Olson EN, Spizz G, Tainsky MA: The oncogenic forms of $\mathrm{N}$-ras or H-ras prevent skeletal myoblast differentiation. Mol Cell Biol 1987, 7:2104-2111.

91. Gossett LA, Zhang W, Olson EN: Dexamethasone-dependent inhibition of differentiation of C2 myoblasts bearing steroid-inducible $\mathrm{N}$-ras oncogenes. J Cell Biol 1988, 106:2127-2137.

92. Bennett AM, Tonks NK: Regulation of distinct stages of skeletal muscle differentiation by mitogen-activated protein kinases. Science 1997, 278:1288-1291.

93. Sarbassov DD, Jones LG, Peterson CA: Extracellular signal-regulated kinase- 1 and -2 respond differently to mitogenic and differentiative signaling pathways in myoblasts. Mol Endocrinol 1997, 11:2038-2047.

94. Rommel C, Clarke BA, Zimmermann S, Nuñez L, Rossman R, Reid K, Moelling K, Yancopoulos GD, Glass DJ: Differentiation stage-specific inhibition of the Raf-MEK-ERK pathway by Akt. Science 1999, 286:1738-1741

95. Wu Z, Woodring PJ, Bhakta KS, Tamura K, Wen F, Feramisco JR, Karin M, Wang JY, Puri PL: p38 and extracellular signal-regulated kinases regulate the myogenic program at multiple steps. Mol Cell Biol 2000, 20:3951-3964.

96. Winter B, Arnold HH: Activated raf kinase inhibits muscle cell differentiation through a MEF2-dependent mechanism. J Cell Sci 2000, 113:4211-4220.
97. Khurana A, Dey CS: Subtype specific roles of mitogen activated protein kinases in L6E9 skeletal muscle cell differentiation. Mol Cell Biochem 2002, 238:27-39

98. Wang $X$, Thomson SR, Starkey JD, Page JL, Ealy AD, Johnson SE: Transforming growth factor $\beta_{1}$ is up-regulated by activated Raf in skeletal myoblasts but does not contribute to the differentiationdefective phenotype. J Biol Chem 2004, 279:2528-2534.

99. Tiffin N, Adi S, Stokoe D, Wu NY, Rosenthal SM: Akt phosphorylation is not sufficient for insulin-like growth factor-stimulated myogenin expression but must be accompanied by down-regulation of mitogen-activated protein kinase/extracellular signal-regulated kinase phosphorylation. Endocrinology 2004, 145:4991-4996.

100. Rossi S, Stoppani E, Puri PL, Fanzani A: Differentiation of human rhabdomyosarcoma RD cells is regulated by reciprocal, functional interactions between myostatin, p38 and extracellular regulated kinase signalling pathways. Eur J Cancer 2011, 47:1095-1105.

101. Lassar AB, Thayer MJ, Overell RW, Weintraub H: Transformation by activated ras or fos prevents myogenesis by inhibiting expression of MyoD1. Cell 1989, 58:659-667.

102. Konieczny SF, Drobes BL, Menke SL, Taparowsky EJ: Inhibition of myogenic differentiation by the $\mathrm{H}$-ras oncogene is associated with the down regulation of the MyoD1 gene. Oncogene 1989, 4:473-481.

103. Ramocki MB, Johnson SE, White MA, Ashendel CL, Konieczny SF, Taparowsky EJ: Signaling through mitogen-activated protein kinase and Rac/Rho does not duplicate the effects of activated Ras on skeletal myogenesis. Mol Cell Biol 1997, 17:3547-3555.

104. Gredinger E, Gerber AN, Tamir Y, Tapscott SJ, Bengal E: Mitogen-activated protein kinase pathway is involved in the differentiation of muscle cells. J Biol Chem 1998, 273:10436-10444.

105. Sternberg EA, Spizz G, Perry ME, Olson EN: A ras-dependent pathway abolishes activity of a muscle-specific enhancer upstream from the muscle creatine kinase gene. Mol Cell Biol 1989, 9:594-601.

106. Olwin BB, Hauschka SD: Cell surface fibroblast growth factor and epidermal growth factor receptors are permanently lost during skeletal muscle terminal differentiation in culture. J Cell Biol 1988, 107:761-769.

107. Templeton TJ, Hauschka SD: FGF-mediated aspects of skeletal muscle growth and differentiation are controlled by a high affinity receptor, FGFR1. Dev Biol 1992, 154:169-181.

108. Hamilton DL, Philp A, MacKenzie MG, Baar K: Prolonged activation of S6K1 does not suppress IRS or PI-3 kinase signaling during muscle cell differentiation. BMC Cell Biol 2010, 11:37.

109. Sarbassov DD, Peterson CA: Insulin receptor substrate-1 and phosphatidylinositol 3-kinase regulate extracellular signal-regulated kinase-dependent and -independent signaling pathways during myogenic differentiation. Mol Endocrinol 1998, 12:1870-1878.

110. Ostrovsky O, Bengal E: The mitogen-activated protein kinase cascade promotes myoblast cell survival by stabilizing the cyclin-dependent kinase inhibitor, p21 WAF1 protein. J Biol Chem 2003, 278:21221-21231.

111. Cho YY, Yao K, Bode AM, Bergen HR, Madden BJ, Oh SM, Ermakova S, Kang BS, Choi HS, Shim JH, Dong Z: RSK2 mediates muscle cell differentiation through regulation of NFAT3. J Biol Chem 2007, 282:8380-8392.

112. Han J, Lee JD, Bibbs L, Ulevitch RJ: A MAP kinase targeted by endotoxin and hyperosmolarity in mammalian cells. Science 1994, 265:808-811.

113. Freshney NW, Rawlinson L, Guesdon F, Jones E, Cowley S, Hsuan J, Saklatvala J: Interleukin-1 activates a novel protein kinase cascade that results in the phosphorylation of Hsp27. Cell 1994, 78:1039-1049.

114. Rouse J, Cohen P, Trigon S, Morange M, Alonso-Llamazares A, Zamanillo D, Hunt T, Nebreda AR: A novel kinase cascade triggered by stress and heat shock that stimulates MAPKAP kinase- 2 and phosphorylation of the small heat shock proteins. Cell 1994, 78:1027-1037.

115. Lee JC, Laydon JT, McDonnell PC, Gallagher TF, Kumar S, Green D, McNulty D, Blumenthal MJ, Heys JR, Landvatter SW: A protein kinase involved in the regulation of inflammatory cytokine biosynthesis. Nature 1994, 372:739-746

116. Nagata Y, Takahashi N, Davis RJ, Todokoro K: Activation of p38 MAP kinase and JNK but not ERK is required for erythropoietin-induced erythroid differentiation. Blood 1998, 92:1859-1869.

117. Morooka T, Nishida E: Requirement of p38 mitogen-activated protein kinase for neuronal differentiation in PC12 cells. J Biol Chem 1998, 273:24285-24288. 
118. Engelman JA, Lisanti MP, Scherer PE: Specific inhibitors of p38 mitogenactivated protein kinase block 3T3-L1 adipogenesis. J Biol Chem 1998, 273:32111-32120.

119. Hu Y, Chan E, Wang SX, Li B: Activation of p38 mitogen-activated protein kinase is required for osteoblast differentiation. Endocrinology 2003, 144:2068-2074.

120. Stanton LA, Sabari S, Sampaio AV, Underhill TM, Beier F: p38 MAP kinase signalling is required for hypertrophic chondrocyte differentiation. Biochem J 2004, 378:53-62.

121. Bhat NR, Zhang P, Mohanty SB: p38 MAP kinase regulation of oligodendrocyte differentiation with CREB as a potential target. Neurochem Res 2007, 32:293-302.

122. Cuenda A, Cohen P: Stress-activated protein kinase-2/p38 and a rapamycin-sensitive pathway are required for $\mathrm{C} 2 \mathrm{C} 12$ myogenesis. J Biol Chem 1999, 274:4341-4346.

123. Zetser A, Gredinger E, Bengal E: p38 mitogen-activated protein kinase pathway promotes skeletal muscle differentiation: participation of the Mef2c transcription factor. J Biol Chem 1999, 274:5193-5200.

124. Galbiati F, Volonte D, Engelman JA, Scherer PE, Lisanti MP: Targeted downregulation of caveolin-3 is sufficient to inhibit myotube formation in differentiating $\mathrm{C} 2 \mathrm{C} 12$ myoblasts: transient activation of p38 mitogenactivated protein kinase is required for induction of caveolin-3 expression and subsequent myotube formation. J Biol Chem 1999, 274:30315-30321.

125. Li Y, Jiang B, Ensign WY, Vogt PK, Han J: Myogenic differentiation requires signalling through both phosphatidylinositol 3-kinase and p38 MAP kinase. Cell Signal 2000, 12:751-757.

126. de Angelis L, Zhao J, Andreucci JJ, Olson EN, Cossu G, McDermott JC: Regulation of vertebrate myotome development by the p38 MAP kinase-MEF2 signaling pathway. Dev Biol 2005, 283:171-179.

127. Perdiguero E, Ruiz-Bonilla V, Gresh L, Hui L, Ballestar E, Sousa-Victor P, Baeza-Raja B, Jardí M, Bosch-Comas A, Esteller M, Caelles C, Serrano AL, Wagner EF, Muñoz-Cánoves P: Genetic analysis of p38 MAP kinases in myogenesis: fundamental role of p38a in abrogating myoblast proliferation. EMBO J 2007, 26:1245-1256.

128. Perdiguero E, Ruiz-Bonilla V, Serrano AL, Muñoz-Cánoves P: Genetic deficiency of p38a reveals its critical role in myoblast cell cycle exit: the p38a-JNK connection. Cell Cycle 2007, 6:1298-1303.

129. Ruiz-Bonilla V, Perdiguero E, Gresh L, Serrano AL, Zamora M, Sousa-Victor P, Jardí M, Wagner EF, Muñoz-Cánoves P: Efficient adult skeletal muscle regeneration in mice deficient in p38a, p38 $\gamma$ and p38 $\mathrm{MAP}$ kinases. Cell Cycle 2008, 7:2208-2214.

130. Lechner C, Zahalka MA, Giot JF, Møller NP, Ullrich A: ERK6, a mitogenactivated protein kinase involved in $\mathrm{C} 2 \mathrm{C} 12$ myoblast differentiation. Proc Natl Acad Sci USA 1996, 93:4355-4359.

131. Wang $H, X u Q$, Xiao F, Jiang $Y$, Wu Z: Involvement of the p38 mitogenactivated protein kinase $\alpha, \beta$, and $\gamma$ isoforms in myogenic differentiation. Mol Biol Cell 2008, 19:1519-1528.

132. Takaesu G, Kang JS, Bae GU, Yi MJ, Lee CM, Reddy EP, Krauss RS: Activation of $p 38 \alpha / \beta$ MAPK in myogenesis via binding of the scaffold protein JLP to the cell surface protein Cdo. J Cell Biol 2006, 175:383-388.

133. Kang JS, Bae GU, Yi MJ, Yang YJ, Oh JE, Takaesu G, Zhou YT, Low BC, Krauss RS: A Cdo-Bnip-2-Cdc42 signaling pathway regulates $p 38 a / \beta$ MAPK activity and myogenic differentiation. J Cell Biol 2008, 182:497-507.

134. Lu M, Krauss RS: N-cadherin ligation, but not Sonic hedgehog binding, initiates Cdo-dependent p38a/ $\beta$ MAPK signaling in skeletal myoblasts. Proc Natl Acad Sci USA 2010, 107:4212-4217.

135. Bhatnagar S, Kumar A, Makonchuk DY, Li H, Kumar A: Transforming growth factor- $\beta$-activated kinase 1 is an essential regulator of myogenic differentiation. J Biol Chem 2010, 285:6401-6411.

136. Puri PL, Wu Z, Zhang P, Wood LD, Bhakta KS, Han J, Feramisco JR, Karin M, Wang JY: Induction of terminal differentiation by constitutive activation of p38 MAP kinase in human rhabdomyosarcoma cells. Genes Dev 2000, 14:574-584.

137. Serra C, Palacios D, Mozzetta C, Forcales SV, Morantte I, Ripani M, Jones DR, Du K, Jhala US, Simone C, Puri PL: Functional interdependence at the chromatin level between the MKK6/p38 and IGF1/PI3K/AKT pathways during muscle differentiation. Mol Cell 2007, 28:200-213.

138. Palacios D, Mozzetta C, Consalvi S, Caretti G, Saccone V, Proserpio V, Marquez VE, Valente S, Mai A, Forcales SV, Sartorelli V, Puri PL: TNF/p38a/ polycomb signaling to Pax7 locus in satellite cells links inflammation to the epigenetic control of muscle regeneration. Cell Stem Cell 2010, 7:455-469.

139. Simone C, Forcales SV, Hill DA, Imbalzano AN, Latella L, Puri PL: p38 pathway targets SWI-SNF chromatin-remodeling complex to musclespecific loci. Nat Genet 2004, 36:738-743.

140. Rampalli S, Li L, Mak E, Ge K, Brand M, Tapscott SJ, Dilworth FJ: p38 MAPK signaling regulates recruitment of Ash2L-containing methyltransferase complexes to specific genes during differentiation. Nat Struct Mol Biol 2007, 14:1150-1156.

141. Lluís F, Ballestar E, Suelves M, Esteller M, Muñoz-Cánoves P: E47 phosphorylation by p38 MAPK promotes MyoD/E47 association and muscle-specific gene transcription. EMBO J 2005, 24:974-984.

142. Baeza-Raja B, Muñoz-Cánoves P: p38 MAPK-induced nuclear factor-kB activity is required for skeletal muscle differentiation: role of interleukin6. Mol Biol Cell 2004, 15:2013-2026.

143. Gonzalez I, Tripathi G, Carter EJ, Cobb LJ, Salih DAM, Lovett FA, Holding C, Pell JM: Akt2, a novel functional link between p38 mitogen-activated protein kinase and phosphatidylinositol 3-kinase pathways in myogenesis. Mol Cell Biol 2004, 24:3607-3622.

144. Cabane C, Coldefy AS, Yeow K, Dérijard B: The p38 pathway regulates Akt both at the protein and transcriptional activation levels during myogenesis. Cell Signal 2004, 16:1405-1415.

145. Lovett FA, Cosgrove RA, Gonzalez I, Pell JM: Essential role for p38a MAPK but not $\mathrm{p} 38 \mathrm{\gamma}$ MAPK in Igf2 expression and myoblast differentiation. Endocrinology 2010, 151:4368-4380.

146. Briata P, Forcales SV, Ponassi M, Corte G, Chen CY, Karin M, Puri PL, Gherzi R: p38-dependent phosphorylation of the mRNA decaypromoting factor KSRP controls the stability of select myogenic transcripts. Mol Cell 2005, 20:891-903.

147. Weston AD, Sampaio AV, Ridgeway AG, Underhill TM: Inhibition of p38 MAPK signaling promotes late stages of myogenesis. J Cell Sci 2003, 116:2885-2893.

148. Staal SP: Molecular cloning of the akt oncogene and its human homologues AKT1 and AKT2: amplification of AKT1 in a primary human gastric adenocarcinoma. Proc Natl Acad Sci USA 1987, 84:5034-5037.

149. Coffer PJ, Woodgett JR: Molecular cloning and characterisation of a novel putative protein-serine kinase related to the CAMP-dependent and protein kinase C families. Eur J Biochem 1991, 201:475-481.

150. Bellacosa A, Testa JR, Staal SP, Tsichlis PN: A retroviral oncogene, akt, encoding a serine-threonine kinase containing an SH2-like region. Science 1991, 254:274-277.

151. Jones PF, Jakubowicz T, Pitossi FJ, Maurer F, Hemmings BA: Molecular cloning and identification of a serine/threonine protein kinase of the second-messenger subfamily. Proc Natl Acad Sci USA 1991, 88:4171-4175.

152. Downward J: Signal transduction: a target for PI(3) kinase. Nature 1995, 376:553-554.

153. Konishi H, Kuroda S, Tanaka M, Matsuzaki H, Ono Y, Kameyama K, Haga T, Kikkawa U: Molecular cloning and characterization of a new member of the RAC protein kinase family: association of the pleckstrin homology domain of three types of RAC protein kinase with protein kinase $C$ subspecies and $\beta \gamma$ subunits of $G$ proteins. Biochem Biophys Res Commun 1995, 216:526-534

154. Glass DJ: Signalling pathways that mediate skeletal muscle hypertrophy and atrophy. Nat Cell Biol 2003, 5:87-90.

155. Franke TF: PI3K/Akt: getting it right matters. Oncogene 2008, 27:6473-6488.

156. Dong LQ, Liu F: PDK2: the missing piece in the receptor tyrosine kinase signaling pathway puzzle. Am J Physiol Endocrinol Metab 2005, 289: E187-E196.

157. Elia D, Madhala D, Ardon E, Reshef R, Halevy O: Sonic hedgehog promotes proliferation and differentiation of adult muscle cells: involvement of MAPK/ERK and PI3K/Akt pathways. Biochim Biophys Acta 2007, 1773:1438-1446.

158. Bae GU, Lee JR, Kim BG, Han JW, Leem YE, Lee HJ, Ho SM, Hahn MJ, Kang JS: Cdo interacts with APPL1 and activates Akt in myoblast differentiation. Mol Biol Cell 2010, 21:2399-2411.

159. Mao X, Kikani CK, Riojas RA, Langlais P, Wang L, Ramos FJ, Fang Q, ChristRoberts CY, Hong JY, Kim RY, Liu F, Dong LQ: APPL1 binds to adiponectin receptors and mediates adiponectin signalling and function. Nat Cell Biol 2006, 8:516-523. 
160. Saito T, Jones CC, Huang S, Czech MP, Pilch PF: The interaction of Akt with APPL1 is required for insulin-stimulated Glut4 translocation. J Biol Chem 2007, 282:32280-32287.

161. Florini JR, Magri KA, Ewton DZ, James PL, Grindstaff K, Rotwein PS: "Spontaneous" differentiation of skeletal myoblasts is dependent upon autocrine secretion of insulin-like growth factor-II. J Biol Chem 1991 266:15917-15923.

162. Stewart CE, Rotwein P: Insulin-like growth factor-II is an autocrine survival factor for differentiating myoblasts. J Biol Chem 1996, 271:11330-11338.

163. Stewart $C E$, James $P L$, Fant ME, Rotwein P: Overexpression of insulin-like growth factor-II induces accelerated myoblast differentiation. J Cell Physiol 1996, 169:23-32

164. Musarò A, Rosenthal N: Maturation of the myogenic program is induced by postmitotic expression of insulin-like growth factor I. Mol Cell Biol 1999, 19:3115-3124.

165. Semsarian C, Sutrave P, Richmond DR, Graham RM: Insulin-like growth factor (IGF-I) induces myotube hypertrophy associated with an increase in anaerobic glycolysis in a clonal skeletal-muscle cell model. Biochem J 1999, 339:443-451.

166. Musarò A, McCullagh KJ, Naya FJ, Olson EN, Rosenthal N: IGF-1 induces skeletal myocyte hypertrophy through calcineurin in association with GATA-2 and NF-ATc1. Nature 1999, 400:581-585.

167. Tureckova J, Wilson EM, Cappalonga JL, Rotwein P: Insulin-like growth factor-mediated muscle differentiation: collaboration between phosphatidylinositol 3-kinase-Akt-signaling pathways and myogenin. J Biol Chem 2001, 276:39264-39270.

168. Coleman ME, DeMayo F, Yin KC, Lee HM, Geske R, Montgomery C, Schwartz RJ: Myogenic vector expression of insulin-like growth factor I stimulates muscle cell differentiation and myofiber hypertrophy in transgenic mice. J Biol Chem 1995, 270:12109-12116.

169. Barton-Davis ER, Shoturma DI, Musarò A, Rosenthal N, Sweeney HL: Vira mediated expression of insulin-like growth factor I blocks the agingrelated loss of skeletal muscle function. Proc Natl Acad Sci USA 1998, 95:15603-15607.

170. Musarò A, McCullagh K, Paul A, Houghton L, Dobrowolny G, Molinaro M, Barton ER, Sweeney HL, Rosenthal N: Localized Igf-1 transgene expression sustains hypertrophy and regeneration in senescent skeletal muscle. Nat Genet 2001, 27:195-200.

171. Fujio Y, Guo K, Mano T, Mitsuuchi Y, Testa JR, Walsh K: Cell cycle withdrawal promotes myogenic induction of Akt, a positive modulator of myocyte survival. Mol Cell Biol 1999, 19:5073-5082.

172. Tamir Y, Bengal E: Phosphoinositide 3-kinase induces the transcriptional activity of MEF2 proteins during muscle differentiation. J Biol Chem 2000, 275:34424-34432.

173. Bodine SC, Stitt TN, Gonzalez M, Kline WO, Stover GL, Bauerlein R, Zlotchenko E, Scrimgeour A, Lawrence JC, Glass DJ, Yancopoulos GD: Akt/ mTOR pathway is a crucial regulator of skeletal muscle hypertrophy and can prevent muscle atrophy in vivo. Nat Cell Biol 2001, 3:1014-1019.

174. Pallafacchina G, Calabria E, Serrano AL, Kalhovde JM, Schiaffino S: A protein kinase B-dependent and rapamycin-sensitive pathway controls skeletal muscle growth but not fiber type specification. Proc Natl Acad Sci USA 2002, 99:9213-9218.

175. Lai KMV, Gonzalez M, Poueymirou WT, Kline WO, Na E, Zlotchenko E, Stitt TN, Economides AN, Yancopoulos GD, Glass DJ: Conditional activation of akt in adult skeletal muscle induces rapid hypertrophy. Mol Cell Biol 2004, 24:9295-9304.

176. Vandromme M, Rochat A, Meier R, Carnac G, Besser D, Hemmings BA, Fernandez A, Lamb NJ: Protein kinase Bß/Akt2 plays a specific role in muscle differentiation. J Biol Chem 2001, 276:8173-8179.

177. Héron-Milhavet L, Franckhauser C, Rana V, Berthenet C, Fisher D, Hemmings BA, Fernandez A, Lamb NJC: Only Akt1 is required for proliferation, while Akt2 promotes cell cycle exit through p21 binding. Mol Cell Biol 2006, 26:8267-8280.

178. Altomare DA, Guo K, Cheng JQ, Sonoda G, Walsh K, Testa JR: Cloning, chromosomal localization and expression analysis of the mouse Akt2 oncogene. Oncogene 1995, 11:1055-1060.

179. Altomare DA, Lyons GE, Mitsuuchi Y, Cheng JQ, Testa JR: Akt2 mRNA is highly expressed in embryonic brown fat and the AKT2 kinase is activated by insulin. Oncogene 1998, 16:2407-2411.

180. Calera MR, Pilch PF: Induction of Akt-2 correlates with differentiation in Sol8 muscle cells. Biochem Biophys Res Commun 1998, 251:835-841.
181. Kaneko S, Feldman Rl, Yu L, Wu Z, Gritsko T, Shelley SA, Nicosia SV, Nobori T, Cheng JQ: Positive feedback regulation between Akt2 and MyoD during muscle differentiation: cloning of Akt2 promoter. J Biol Chem 2002, 277:23230-23235.

182. Rochat A, Fernandez A, Vandromme M, Molès JP, Bouschet T, Carnac G, Lamb NJC: Insulin and wnt1 pathways cooperate to induce reserve cell activation in differentiation and myotube hypertrophy. Mol Biol Cell 2004, 15:4544-4555.

183. Héron-Milhavet L, Mamaeva D, Rochat A, Lamb NJC, Fernandez A: Akt2 is implicated in skeletal muscle differentiation and specifically binds Prohibitin2/REA. J Cell Physiol 2008, 214:158-165.

184. Sumitani S, Goya K, Testa JR, Kouhara H, Kasayama S: Akt1 and Akt2 differently regulate muscle creatine kinase and myogenin gene transcription in insulin-induced differentiation of $\mathrm{C} 2 \mathrm{C} 12$ myoblasts. Endocrinology 2002, 143:820-828.

185. Rosenthal SM, Cheng ZQ: Opposing early and late effects of insulin-like growth factor I on differentiation and the cell cycle regulatory retinoblastoma protein in skeletal myoblasts. Proc Natl Acad Sci USA 1995, 92:10307-10311.

186. Engert JC, Berglund EB, Rosenthal N: Proliferation precedes differentiation in IGF-I-stimulated myogenesis. J Cell Biol 1996, 135:431-440.

187. Machida S, Spangenburg EE, Booth FW: Forkhead transcription factor FoxO1 transduces insulin-like growth factor's signal to $\mathrm{p} 27^{\text {Kip } 1}$ in primary skeletal muscle satellite cells. J Cell Physiol 2003, 196:523-531.

188. Viñals F, Pouysségur J: Confluence of vascular endothelial cells induces cell cycle exit by inhibiting p42/p44 mitogen-activated protein kinase activity. Mol Cell Biol 1999, 19:2763-2772.

189. Suzuki E, Nagata D, Yoshizumi M, Kakoki M, Goto A, Omata M, Hirata Y: Reentry into the cell cycle of contact-inhibited vascular endothelial cells by a phosphatase inhibitor: possible involvement of extracellular signalregulated kinase and phosphatidylinositol 3-kinase. J Biol Chem 2000, 275:3637-3644.

190. Jacobsen K, Groth A, Willumsen BM: Ras-inducible immortalized fibroblasts: focus formation without cell cycle deregulation. Oncogene 2002, 21:3058-3067.

191. Zhang L, Bewick M, Lafrenie RM: Role of Raf-1 and FAK in cell densitydependent regulation of integrin-dependent activation of MAP kinase. Carcinogenesis 2002, 23:1251-1258.

192. Gherzi R, Trabucchi M, Ponassi M, Gallouzi IE, Rosenfeld MG, Briata P: Akt2mediated phosphorylation of Pitx2 controls Cond1 mRNA decay during muscle cell differentiation. Cell Death Differ 2010, 17:975-983.

193. Hribal ML, Nakae J, Kitamura T, Shutter JR, Accili D: Regulation of insulinlike growth factor-dependent myoblast differentiation by Foxo forkhead transcription factors. J Cell Biol 2003, 162:535-541.

194. Xu Q, Wu Z: The insulin-like growth factor-phosphatidylinositol 3-kinaseAkt signaling pathway regulates myogenin expression in normal myogenic cells but not in rhabdomyosarcoma-derived RD cells. J Biol Chem 2000, 275:36750-36757.

195. Cabane C, Coldefy AS, Yeow K, Dérijard B: The p38 pathway regulates Akt both at the protein and transcriptional activation levels during myogenesis. Cell Signal 2004, 16:1405-1415.

196. van der Velden JLJ, Langen RCJ, Kelders MCJM, Wouters EFM, JanssenHeininger YMW, Schols AMWJ: Inhibition of glycogen synthase kinase-3 $\beta$ activity is sufficient to stimulate myogenic differentiation. Am J Physiol Cell Physiol 2006, 290:C453-C462.

197. van der Velden JUJ, Schols AMWJ, Willems J, Kelders MCJM, Langen RCJ: Glycogen synthase kinase 3 suppresses myogenic differentiation through negative regulation of NFATC3. J Biol Chem 2008, 283:358-366.

198. Pansters NAM, van der Velden JU, Kelders MCJM, Laeremans $H$ Schols AMWJ, Langen RCJ: Segregation of myoblast fusion and musclespecific gene expression by distinct ligand-dependent inactivation of GSK-3ß. Cell Mol Life Sci 2011, 68:523-535.

199. Wilson EM, Tureckova J, Rotwein P: Permissive roles of phosphatidyl inositol 3-kinase and Akt in skeletal myocyte maturation. Mol Biol Cell 2004, 15:497-505.

200. Rommel C, Bodine SC, Clarke BA, Rossman R, Nunez L, Stitt TN, Yancopoulos GD, Glass DJ: Mediation of IGF-1-induced skeletal myotube hypertrophy by $\mathrm{PI}(3) \mathrm{K} / \mathrm{Akt} / \mathrm{mTOR}$ and $\mathrm{PI}(3) \mathrm{K} / \mathrm{Akt} / \mathrm{GSK} 3$ pathways. Nat Cell Biol 2001, 3:1009-1013. 
201. Vyas DR, Spangenburg EE, Abraha TW, Childs TE, Booth FW: GSK-3 $\beta$ negatively regulates skeletal myotube hypertrophy. Am J Physiol Cell Physiol 2002, 283:C545-C551.

202. Sandri M, Sandri C, Gilbert A, Skurk C, Calabria E, Picard A, Walsh K, Schiaffino S, Lecker SH, Goldberg AL: Foxo transcription factors induce the atrophy-related ubiquitin ligase atrogin-1 and cause skeletal muscle atrophy. Cell 2004, 117:399-412.

203. Stitt TN, Drujan D, Clarke BA, Panaro F, Timofeyva Y, Kline WO, Gonzalez M, Yancopoulos GD, Glass DJ: The IGF-1/PI3K/Akt pathway prevents expression of muscle atrophy-induced ubiquitin ligases by inhibiting FOXO transcription factors. Mol Cell 2004, 14:395-403.

204. Park IH, Erbay E, Nuzzi $P$, Chen J: Skeletal myocyte hypertrophy requires mTOR kinase activity and S6K1. Exp Cell Res 2005, 309:211-219.

205. Erbay $E$, Chen J: The mammalian target of rapamycin regulates $\mathrm{C} 2 \mathrm{C} 12$ myogenesis via a kinase-independent mechanism. J Biol Chem 2001, 276:36079-36082.

206. Shu L, Zhang X, Houghton PJ: Myogenic differentiation is dependent on both the kinase function and the N-terminal sequence of mammalian target of rapamycin. J Biol Chem 2002, 277:16726-16732.

207. Erbay E, Park IH, Nuzzi PD, Schoenherr CJ, Chen J: IGF-II transcription in skeletal myogenesis is controlled by mTOR and nutrients. J Cell Biol 2003, 163:931-936.

208. Shu L, Houghton PJ: The mTORC2 complex regulates terminal differentiation of C2C12 myoblasts. Mol Cell Biol 2009, 29:4691-4700.

209. Ge Y, Wu AL, Warnes C, Liu J, Zhang C, Kawasome H, Terada N, Boppart MD, Schoenherr CJ, Chen J: mTOR regulates skeletal muscle regeneration in vivo through kinase-dependent and kinase-independent mechanisms. Am J Physiol Cell Physiol 2009, 297:C1434-C1444.

210. Latres E, Amini AR, Amini AA, Griffiths J, Martin FJ, Wei Y, Lin HC, Yancopoulos GD, Glass DJ: Insulin-like growth factor-1 (IGF-1) inversely regulates atrophy-induced genes via the phosphatidylinositol 3-kinase/ Akt/mammalian target of rapamycin (PI3K/Akt/mTOR) pathway. J Biol Chem 2005, 280:2737-2744

211. Ohanna M, Sobering AK, Lapointe T, Lorenzo L, Praud C, Petroulakis E,

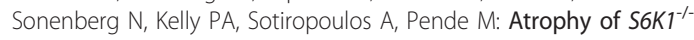
skeletal muscle cells reveals distinct mTOR effectors for cell cycle and size control. Nat Cell Biol 2005, 7:286-294.

212. Sun Y, Ge Y, Drnevich J, Zhao Y, Band M, Chen J: Mammalian target of rapamycin regulates miRNA-1 and follistatin in skeletal myogenesis. $J$ Cell Biol 2010, 189:1157-1169.

213. Allen RE, Sheehan SM, Taylor RG, Kendall TL, Rice GM: Hepatocyte growth factor activates quiescent skeletal muscle satellite cells in vitro. J Cell Physiol 1995, 165:307-312.

214. Tatsumi R, Anderson JE, Nevoret CJ, Halevy O, Allen RE: HGF/SF is present in normal adult skeletal muscle and is capable of activating satellite cells. Dev Biol 1998, 194:114-128.

215. Miller KJ, Thaloor D, Matteson S, Pavlath GK: Hepatocyte growth factor affects satellite cell activation and differentiation in regenerating skeletal muscle. Am J Physiol Cell Physiol 2000, 278:C174-C181.

216. Sun L, Ma K, Wang H, Xiao F, Gao Y, Zhang W, Wang K, Gao X, Ip N, Wu Z: JAK1-STAT1-STAT3, a key pathway promoting proliferation and preventing premature differentiation of myoblasts. J Cell Biol 2007, 179:129-138.

217. Gillespie MA, Le Grand F, Scimè A, Kuang S, von Maltzahn J, Seale V, Cuenda A, Ranish JA, Rudnicki MA: p38- $\gamma$-dependent gene silencing restricts entry into the myogenic differentiation program. J Cell Biol 2009, 187:991-1005.

218. Nishiyama T, Kii I, Kudo A: Inactivation of Rho/ROCK signaling is crucial for the nuclear accumulation of FKHR and myoblast fusion. $J$ Biol Chem 2004, 279:47311-47319.

219. Castellani L, Salvati E, Alemà S, Falcone G: Fine regulation of RhoA and Rock is required for skeletal muscle differentiation. J Biol Chem 2006, 281:15249-15257.

220. Lim MJ, Choi KJ, Ding Y, Kim JH, Kim BS, Kim YH, Lee J, Choe W, Kang I, Ha J, Yoon KS, Kim SS: RhoA/Rho kinase blocks muscle differentiation via serine phosphorylation of insulin receptor substrate-1 and -2. Mol Endocrinol 2007, 21:2282-2293.

221. Bae GU, Kim BG, Lee HJ, Oh JE, Lee SJ, Zhang W, Krauss RS, Kang JS: Cdo binds $\mathrm{Abl}$ to promote $\mathrm{p} 38 \mathrm{a} / \mathrm{\beta}$ mitogen-activated protein kinase activity and myogenic differentiation. Mol Cell Biol 2009, 29:4130-4143.
222. di Bari MG, Ciuffini L, Mingardi M, Testi R, Soddu S, Barilà D: c-Abl acetylation by histone acetyltransferases regulates its nuclearcytoplasmic localization. EMBO Rep 2006, 7:727-733.

223. Lu J, McKinsey TA, Zhang CL, Olson EN: Regulation of skeletal myogenesis by association of the MEF2 transcription factor with class II histone deacetylases. Mol Cell 2000, 6:233-244.

224. McKinsey TA, Zhang CL, Olson EN: Activation of the myocyte enhancer factor-2 transcription factor by calcium/calmodulin-dependent protein kinase-stimulated binding of 14-3-3 to histone deacetylase 5. Proc Natl Acad Sci USA 2000, 97:14400-14405.

225. McKinsey TA, Zhang CL, Lu J, Olson EN: Signal-dependent nuclear export of a histone deacetylase regulates muscle differentiation. Nature 2000, 408:106-111.

226. Xu Q, Yu L, Liu L, Cheung CF, Li X, Yee SP, Yang XJ, Wu Z: p38 mitogenactivated protein kinase-, calcium-calmodulin-dependent protein kinase-, and calcineurin-mediated signaling pathways transcriptionally regulate myogenin expression. Mol Biol Cell 2002, 13:1940-1952.

227. Deng X, Ewton DZ, Pawlikowski B, Maimone M, Friedman E: Mirk/dyrk1B is a Rho-induced kinase active in skeletal muscle differentiation. J Biol Chem 2003, 278:41347-41354.

228. Deng X, Ewton DZ, Mercer SE, Friedman E: Mirk/dyrk1B decreases the nuclear accumulation of class II histone deacetylases during skeletal muscle differentiation. J Biol Chem 2005, 280:4894-4905.

229. Dinev D, Jordan BW, Neufeld B, Lee JD, Lindemann D, Rapp UR, Ludwig S: Extracellular signal regulated kinase 5 (ERK5) is required for the differentiation of muscle cells. EMBO Rep 2001, 2:829-834.

230. Carter EJ, Cosgrove RA, Gonzalez I, Eisemann JH, Lovett FA, Cobb L, Pell JM: MEK5 and ERK5 are mediators of the pro-myogenic actions of IGF-2. J Cell Sci 2009, 122:3104-3112.

231. Wang $K$, Wang $C$, Xiao F, Wang $H$, Wu Z: JAK2/STAT2/STAT3 are required for myogenic differentiation. J Biol Chem 2008, 283:34029-34036.

232. Kleger A, Loebnitz C, Pusapati GV, Armacki M, Müller M, Tümpel S, Illing A, Hartmann D, Brunner C, Liebau S, Rudolph KL, Adler G, Seufferlein T: Protein kinase D2 is an essential regulator of murine myoblast differentiation. PLoS One 2011, 6:e14599.

233. Bois PRJ, Brochard VF, Salin-Cantegrel AVA, Cleveland JL, Grosveld GC: FoxO1a-cyclic GMP-dependent kinase I interactions orchestrate myoblast fusion. Mol Cell Biol 2005, 25:7645-7656.

234. Madaro L, Marrocco V, Fiore P, Aulino P, Smeriglio P, Adamo S, Molinaro M, Bouché $\mathrm{M}$ : PKCO signaling is required for myoblast fusion by regulating the expression of caveolin-3 and $\beta 1 D$ integrin upstream focal adhesion kinase. Mol Biol Cell 2011, 22:1409-1419.

235. Quach NL, Biressi S, Reichardt LF, Keller C, Rando TA: Focal adhesion kinase signaling regulates the expression of caveolin 3 and $\beta 1$ integrin, genes essential for normal myoblast fusion. Mol Biol Cell 2009, 20:3422-3435.

236. Pelosi M, Marampon F, Zani BM, Prudente S, Perlas E, Caputo V, Cianetti L, Berno V, Narumiya S, Kang SW, Musarò A, Rosenthal N: ROCK2 and its alternatively spliced isoform ROCK2m positively control the maturation of the myogenic program. Mol Cell Biol 2007, 27:6163-6176.

doi:10.1186/2044-5040-1-29

Cite this article as: Knight and Kothary: The myogenic kinome: protein kinases critical to mammalian skeletal myogenesis. Skeletal Muscle 2011 $1: 29$.

\section{Submit your next manuscript to BioMed Central and take full advantage of:}

- Convenient online submission

- Thorough peer review

- No space constraints or color figure charges

- Immediate publication on acceptance

- Inclusion in PubMed, CAS, Scopus and Google Scholar

- Research which is freely available for redistribution

Submit your manuscript at www.biomedcentral.com/submit
C Biomed Central 